\title{
Structure of $\mathrm{Ca}^{2+-B o u n d ~ S 100 A 4}$ and Its Interaction with Peptides Derived from Nonmuscle Myosin-IIA ${ }^{\dagger}$
}

\author{
Vladimir N. Malashkevich $\ddagger, \S$, Kristen M. Varney $\S, \|$, Sarah C. Garrett ${ }^{\ddagger}, \S$, Paul T. Wilder $\|$, \\ David Knight ${ }^{\ddagger}, \perp$, Thomas H. Charpentier $\|$, Udupi A. Ramagopal $¥$, Steven C. Almo ${ }^{\star}, \neq$, David \\ J. Weber ${ }^{\star}, \|$, and Anne R. Bresnick ${ }^{\star}, \neq$ \\ $\$$ Department of Biochemistry, Albert Einstein College of Medicine, 1300 Morris Park Avenue, Bronx, New \\ York 10461 \\ II Department of Biochemistry and Molecular Biology, University of Maryland School of Medicine, 108 North \\ Greene Street, Baltimore, Maryland 21201
}

\section{Abstract}

$\mathrm{S} 100 \mathrm{~A} 4$, also known as mts1, is a member of the $\mathrm{S} 100$ family of $\mathrm{Ca}^{2+}$-binding proteins that is directly involved in tumor invasion and metastasis via interactions with specific protein targets, including nonmuscle myosin-IIA (MIIA). Human S100A4 binds two $\mathrm{Ca}^{2+}$ ions with the typical EF-hand exhibiting an affinity that is nearly 1 order of magnitude tighter than that of the pseudo-EF-hand. To examine how $\mathrm{Ca}^{2+}$ modifies the overall organization and structure of the protein, we determined the $1.7 \AA$ crystal structure of the human $\mathrm{Ca}^{2+}-\mathrm{S} 100 \mathrm{~A} 4 . \mathrm{Ca}^{2+}$ binding induces a large reorientation of helix 3 in the typical EF-hand. This reorganization exposes a hydrophobic cleft that is comprised of residues from the hinge region, helix 3 , and helix 4 , which afford specific target recognition and binding. The $\mathrm{Ca}^{2+}$-dependent conformational change is required for S100A4 to bind peptide sequences derived from the C-terminal portion of the MIIA rod with submicromolar affinity. In addition, the level of binding of $\mathrm{Ca}^{2+}$ to both EF-hands increases by 1 order of magnitude in the presence of MIIA. NMR spectroscopy studies demonstrate that following titration with a MIIA peptide, the largest chemical shift perturbations and exchange broadening effects occur for residues in the hydrophobic pocket of $\mathrm{Ca}^{2+}{ }_{-} \mathrm{S} 100 \mathrm{~A} 4$. Most of these residues are not exposed in apo-S100A4 and explain the $\mathrm{Ca}^{2+}$ dependence of formation of the S100A4-MIIA complex. These studies provide the foundation for understanding S100A4 target recognition and may support the development of reagents that interfere with S100A4 function.

S100A4, also called mts1, is a member of the S100 family of small, homodimeric, EF-hand $\mathrm{Ca}^{2+}$ binding proteins. S100 proteins are expressed in a tissue specific manner and bind to a variety of target proteins, resulting in the regulation of specific cellular processes, including cell-cycle regulation, protein phosphorylation, cell growth, motility, differentiation, and survival (1-4). While S100A4 is expressed in a wide range of normal tissues $(5,6)$, it is recognized that an increased level of S100A4 expression correlates with a high incidence of metastasis and poor prognosis for cancer patients $(7,8)$. High S100A4 expression levels are associated with several metastatic cancers, including breast (9), colorectal (10), bladder (11),

\footnotetext{
${ }^{\dagger}$ This work was supported by National Institutes of Health Grants GM069945 (A.R.B.), GM58888 (D.J.W.), and CA107331 (D.J.W.) and American Cancer Society Grant CDD107745 (D.J.W.).

*To whom correspondence should be addressed: A.R.B.: telephone, (718) 430-2741; fax, (718) 430-8565; e-mail, bresnick@aecom.yu.edu. D.J.W.: telephone, (410) 706-4354; fax, (410) 706-0458; e-mail, dweber@umaryland.edu. S.C.A.: telephone, (718) 430-2746; fax, (718) 430-8565; e-mail, almo@ aecom.yu.edu.

These authors contributed equally to the completion of this work.

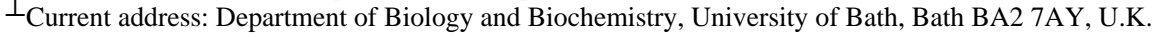


esophageal (12), non-small cell lung (13), gastric (14), medulloblastoma (15), pancreatic (16), prostate (17), and thyroid (18). In colorectal cancer, S100A4 is a direct transcriptional target of the $\beta$-catenin-T-cell factor (TCF) complex (19), a component of the Wnt $/ \beta$-catenin pathway that is frequently unregulated as a result of mutations that affect the phosphorylation and stabilization of $\beta$-catenin (20-22). In medulloblastoma, enhanced S100A4 expression occurs via ErbB2 signaling and the PI3K/Akt and Erk 1/2 pathways (15). These findings suggest that multiple signaling cascades can lead to elevated S100A4 levels.

S100A4-induced metastasis observed in vivo is thought to result from S100A4-mediated increases in motility and invasion observed at the cellular level $(8,19)$. At the molecular level, S100A4 is recognized as a $\mathrm{Ca}^{2+}$-activated switch $(8,23)$, which in the $\mathrm{Ca}^{2+}$-loaded form adopts a conformation that allows it to bind target proteins. Cytoskeletal and signaling targets of S100A4 include nonmuscle myosin-IIA (24,25), tropomyosin (26), F-actin (27), and liprin $\beta 1$, an interacting protein of the LAR family of transmembrane tyrosine phosphatases (28).

The $\mathrm{Ca}^{2+}$-dependent interaction of S100A4 with myosin-IIA prevents oligomerization and promotes the monomeric, unassembled state of myosin-IIA (29). This observation is consistent with data showing that the S100A4 binding site maps to the C-terminal end of the coiled coil of the myosin-IIA heavy chain (29) and that the S100A4 binding site overlaps the extended assembly competence domain, which is required for myosin-II assembly (30,31). Furthermore, phosphorylation by casein kinase 2 on Ser1943 of the myosin-IIA heavy chain, which is downstream of the S100A4 binding site, inhibits S100A4 binding and protects against S100A4induced disassembly of myosin-IIA filaments $(29,32)$. Thus, heavy chain phosphorylation, as well as $\mathrm{Ca}^{2+}$ binding, regulates the S100A4-myosin-IIA interaction. In addition, S100A4 modulates the polarization and motility of carcinoma cells through a direct interaction with myosin-IIA (33). This interaction likely plays a role in the contribution of S100A4 to metastasis (8).

The interaction of S100A4 with myosin-IIA is strictly $\mathrm{Ca}^{2+}$-dependent $(25,29)$. Similar to other S100 proteins, S100A4 is a symmetric homodimer with each subunit containing two EF-hand $\mathrm{Ca}^{2+}$-binding loops: a C-terminal typical EF-hand and an N-terminal pseudo-EF-hand comprised of 14 residues (instead of 12). The apo-S100A4 consists of four helices and a small $\beta$-sheet with two helices from each subunit $\left(1,4,1^{\prime}\right.$, and $\left.4^{\prime}\right)$ forming a tight X-type four-helix bundle that comprises the dimer interface (23). When $\mathrm{Ca}^{2+}$ binds, helix 3 in each S100A4 subunit rotates by $\sim 60^{\circ}$ relative to helix 4 and exposes a hydrophobic cleft in a manner similar to that observed for other S100 proteins (34-36).

To further characterize the interaction between myosin-IIA and S100A4, we examined the binding of S100A4 to $\mathrm{Ca}^{2+}$ and peptides derived from the C-terminus of myosin-IIA. These data together with the $\mathrm{X}$-ray structure of the $\mathrm{Ca}^{2+}-\mathrm{S} 100 \mathrm{~A} 4$ have allowed us to map the surface on $\mathrm{Ca}^{2+}$-activated S100A4 that interacts with myosin-IIA. Such information is necessary to understand the $\mathrm{Ca}^{2+}$ dependence of the S100A4-MIIA ${ }^{1}$ interaction and could be useful for understanding how S100A4 depolymerizes highly stable myosin-IIA filaments. These results could also aid in the design of S100A4 inhibitors, some of which may hold promise as therapeutic agents for metastatic cancers.

\footnotetext{
${ }^{1}$ Abbreviations: MIIA, nonmuscle myosin-IIA; LAR, leukocyte common antigen related; ITC, isothermal titration calorimetry; DTT, dithiothreitol; TSP, 3-(trimethylsilyl)propionic acid- $d_{4}$, sodium salt; HSQC, heteronuclear single-quantum coherence; NOESY, nuclear Overhauser effect spectroscopy; HOHAHA, homonuclear Hartmann-Hahn spectroscopy; HMQC, heteronuclear multiple-quantum coherence; DIPSI-2, decoupling in the presence of scalar interaction version 2; HPLC, high-performance liquid chromatography; TCEP, tris(2-carboxyethyl)phosphine; FITC, fluorescein isothiocyanate; BAPTA, 1,2-bis( $o$-aminophenoxy)ethane- $N, N, N^{\prime}, N^{\prime}$-tetraacetic acid; $\mathrm{PCP}$, prochlorperazine; ACD, assembly competence domain.
} 


\section{EXPERIMENTAL PROCEDURES}

\section{Bacterial Expression and Purification of Wild-Type and $\triangle 13 \mathrm{C}$ S100A4}

Full-length human S100A4 was cloned into the NdeI/BamHI sites of the pET23a protein expression vector (Novagen Inc.), and the recombinant protein was purified as described previously (29). Protein yields of full-length S100A4 were typically $20 \mathrm{mg}$ of purified protein

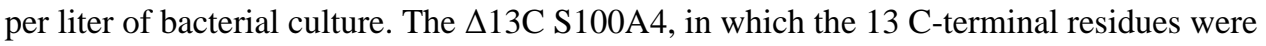
deleted, was cloned into the NdeI/HindIII sites of the pET23a vector. For NMR, the S100A4 protein preparation was modified such that defined medium was used with ${ }^{15} \mathrm{~N}$-labeled $\mathrm{NH}_{4} \mathrm{Cl}$ and ${ }^{13} \mathrm{C}_{6}$-labeled glucose as the only nitrogen and carbon sources, respectively, as described previously (23). Mass spectrometric analysis confirmed the purity of these proteins and indicated that the $\mathrm{N}$-terminal methionine is not present in the purified protein (data not shown).

\section{Peptides}

The S100A4 C-terminal tail peptide (Ac-EFFEGFPDKQPRKK, corresponding to residues Glu88-Lys101 of S100A4), which comprises the immediate C-terminus of S100A4, was synthesized by Biosynthesis Inc. (Lewisville, TX). Myosin-IIA peptides (MIIA ${ }^{1908-1923}$, AcDAMNREVSSLKNKLRR-CONH ${ }_{2}$;FITC-MIIA ${ }^{1908-1923}$,FITC-AhxDAMNREVSSLKNKLRR-OH; MIIA ${ }^{1899-1923}$, AcELEDATETADAMNREVSSLKNKLRR-CONH 2 ; MIIA ${ }^{1893-1923}$, AcRRKLQRELEDATETADAMNREVSSLKNKLRR-CONH ${ }_{2}$ ) were synthesized by Biosynthesis Inc. The FITC peptide used as a probe is not amidated on the $\mathrm{C}$-terminus and has an aminohexanoic acid (Ahx) linker prior to the start of the peptide sequence. The molecular weight and purity (>95\%) of all peptides were verified using mass spectrometry and HPLC, respectively. The concentration values for all peptide solutions were determined by quantitative amino acid analysis.

For experiments with FITC-MIIA ${ }^{1908-1923}$, a 5 mM stock solution was prepared in $20 \mathrm{mM}$ Tris (pH 7.5), $150 \mathrm{mM} \mathrm{KCl}, 1 \mathrm{mM} \mathrm{DTT}$, and $0.02 \% \mathrm{NaN}_{3}$, aliquoted, and stored at $-80{ }^{\circ} \mathrm{C}$. A C-terminal fragment of the human myosin-IIA heavy chain that corresponds to residues 1851-1960 (MIIA ${ }^{1851-1960}$ ) was cloned into the EcoRI/NdeI sites of pET23a. The myosin-IIA tail fragment (MIIA ${ }^{1851-1960}$ ) was expressed in BL21-CodonPlus competent cells without induction (Stratagene, Cedar Creek, TX). Cell pellets were collected, resuspended in a lysis buffer containing $50 \mathrm{mM}$ Tris (pH 7.5), $10 \%$ glycerol, $300 \mathrm{mM} \mathrm{KCl,} 2 \mathrm{mM}$ DTT, $1 \mathrm{mM}$ EDTA, $1 \mathrm{mM}$ PMSF, and chymostatin, leupeptin, and pepstatin $\left(5 \mu \mathrm{g} / \mathrm{mL}\right.$ each), and frozen at $-80^{\circ}$ C. Thawed cell pellets were sonicated, heated to $95^{\circ} \mathrm{C}$ for $25 \mathrm{~min}$, cooled on ice, and spun at $27000 \mathrm{~g}$ for $20 \mathrm{~min}$. The resulting supernatant was dialyzed against $20 \mathrm{mM}$ Tris (pH 7.5) and $0.02 \% \mathrm{NaN}_{3}$ for subsequent purification on a High Q Sepharose anion exchange column. Fractions containing the myosin-IIA tail fragment were pooled and run on a Bio-Rad Bio-Scale Ceramic Hydroxyapatite type I column using a 0.005 to $0.4 \mathrm{M} \mathrm{K}_{2} \mathrm{HPO}_{4}$ gradient. The MIIA ${ }^{1851-1960}$ protein concentration was determined using the modified Lowry assay (Pierce) and a MIIA ${ }^{1851-1960}$ standard at a known concentration. The concentration of the MIIA ${ }^{1851-1960}$ standard was determined by amino acid analysis (Keck Biotechnology Resource Laboratory at Yale University, New Haven, CT).

\section{Protein Crystallization}

The protein was dialyzed into $20 \mathrm{mM}$ Tris (pH 7.5), $20 \mathrm{mM} \mathrm{KCl,} 10 \mathrm{mM}$ DTT, $20 \mathrm{mM}$ $\mathrm{CaCl}_{2}$, and $0.02 \% \mathrm{NaN}_{3}$ and concentrated to $20-30 \mathrm{mg} / \mathrm{mL}(\sim 0.85-1.28 \mathrm{mM}$ dimer) using a 3000 MWCO Millipore Amicon centrifugal concentrator. Prior to crystallization, prochlorperazine (PCP) was added to a final concentration of $5 \mathrm{mM}$. Diffraction quality crystals were obtained by hanging drop vapor diffusion at $21^{\circ} \mathrm{C}$ by mixing $1 \mu \mathrm{L}$ of S100A4 and PCP 
with $1 \mu \mathrm{L}$ of reservoir solution containing $0.05 \mathrm{M}$ ammonium sulfate, $0.05 \mathrm{M}$ Bis-Tris ( $\mathrm{pH}$ $6.5)$, and $27.5 \%$ pentaerythritol ethoxylate $(15 / 4 \mathrm{EO} / \mathrm{OH})$ and equilibrating the samples against reservoir solution for $2-3$ weeks. Diffraction from these crystals is consistent with space group $P 3_{2} 21$ with two S100A4 chains per asymmetric unit and the following unit cell dimensions: $a=b=52.4 \AA, c=140.4 \AA$.

\section{Structure Solution}

Crystals of S100A4 with dimensions of $0.1 \mathrm{~mm} \times 0.1 \mathrm{~mm}$ nitrogen. $\times 0.2 \mathrm{~mm}$ were flashcooled in liquid Single anomalous dispersion (SAD) data (see Table 1) were collected at the X6A beamline (National Synchrotron Light Source, Brookhaven, NY) using an ADSC Q210 CCD detector (Area Detector Systems Corp., Poway, CA) and $1.7 \AA$ wavelength radiation to enhance the anomalous signal from sulfur atoms and $\mathrm{Ca}^{2+}$ ions. Native data were collected on a Quantum 315 CCD detector (Area Detector Systems Corp.) with $1.0 \AA$ wavelength radiation on the X29A beamline (National Synchrotron Light Source). Intensities were integrated using HKL2000 and reduced to amplitudes using TRUNCATE $(37,38)$. Experimental SAD phases were determined using SHELXD (39) and SHELXE (40), and the initial model was generated by the autobuilding algorithm in Arp/wArp (41). Further model building and refinement were performed with REFMAC and COOT $(38,42)$. The quality of the final structure was verified with composite omit maps, and the stereochemistry was checked with WHATCHECK (43) and PROCHECK (44). The final model contained two subunit chains of 96 residues each (Ala2Gln97), four $\mathrm{Ca}^{2+}$ ions, and 226 water molecules with $R_{\text {cryst }}$ and $R_{\text {free }}$ values of 0.197 and 0.222 , respectively. PCP was not visible in either the initial experimental or final refined electron density maps, even though diffraction quality crystals appeared only in the presence of the inhibitor. The LSQKAB and SSM algorithms were used for structural superimpositions $(38,45)$. Structural similarity with other S100 family members was analyzed using DALI $(46,47)$. Interhelix angles and distances were calculated using INTERHLX (48). Quaternary structure and accessible surface areas were analyzed using the PISA server using a $4 \AA$ cutoff (http://www.ebi.ac.uk/msd-srv/prot_int/cgi-bin/piserver). Molecular contacts were analyzed with the program CONTACT (38).

\section{NMR Spectroscopy}

Purified S100A4 was dialyzed against Chelex-100-treated buffer, which included $0.1 \mathrm{mM}$ Tris$d_{11}(\mathrm{pH} 7.5)$ and $0.1 \mathrm{mM}$ DTT, and then lyophilized, redissolved in a small aliquot of $\mathrm{ddH}_{2} \mathrm{O}$, and stored at $-80{ }^{\circ} \mathrm{C}$. The $\mathrm{Ca}^{2+}$-loaded NMR samples contained an S100A4 subunit concentration of $0.25-1 \mathrm{mM}, 0.34 \mathrm{mM} \mathrm{NaN}_{3}, 8 \mathrm{mM} \mathrm{NaCl}, 16 \mathrm{mM}$ Tris- $d_{11}, 0.1 \mathrm{mM}$ EDTA, $6 \mathrm{mM} \mathrm{DTT}, 6 \mathrm{mM} \mathrm{CaCl}_{2}$, and $10 \% \mathrm{D}_{2} \mathrm{O}$. For all NMR samples, the $\mathrm{pH}$ was adjusted with cold $\mathrm{HCl}$ to 6.0 with continuous stirring. Prior to use, stock solutions of all buffer components were passed through a Chelex-100 column to remove any trace metals. NMR data were collected at $37^{\circ} \mathrm{C}$ with either a Bruker DMX $600 \mathrm{NMR}$ spectrometer ( $600.13 \mathrm{MHz}$ for protons) or a Bruker Avance 800 US2 spectrometer ( $800.27 \mathrm{MHz}$ for protons) both equipped with pulsed-field gradients, four frequency channels, and triple-resonance, $z$-axis gradient cryogenic probes. Unless otherwise stated,a1s relaxation delay was used and quadrature detection in the indirect dimensions was obtained with States-TPPI phase cycling (49). Data were processed on Linux workstations (Red Hat version 9.0) using the processing program NMRPipe (50). Time domain data in the indirect dimensions were extended by no more than one-third using standard linear prediction routines (51), except for data in constant time domains that were extended 2 -fold using mirror-image linear prediction (52). All proton chemical shifts are reported with respect to the $\mathrm{H}_{2} \mathrm{O}$ or $\mathrm{HDO}$ signal taken as $4.658 \mathrm{ppm}$ relative to external TSP $(0.0 \mathrm{ppm})$ at $37^{\circ} \mathrm{C}$. The ${ }^{13} \mathrm{C}$ and ${ }^{15} \mathrm{~N}$ chemical shifts were indirectly referenced using the following ratios of zeropoint frequencies at $37{ }^{\circ} \mathrm{C}$ : 0.10132905 for ${ }^{15} \mathrm{~N}$ to ${ }^{1} \mathrm{H}$ and 0.25144953 for ${ }^{13} \mathrm{C}$ to ${ }^{1} \mathrm{H}(53-55)$. 
Uniformly ${ }^{15} \mathrm{~N}$-labeled S100A4 was used to collect the two-dimensional (2D) ${ }^{1} \mathrm{H}-{ }^{15} \mathrm{~N}$ fast HSQC spectrum (56), the three-dimensional (3D) ${ }^{15} \mathrm{~N}$-edited NOESY-HSQC spectrum with a 100 ms mixing time (57), the $3 \mathrm{D}^{15} \mathrm{~N}$-edited HOHAHA-HSQC spectrum with a $60 \mathrm{~ms}$ DIPSI-2rc spin-lock and a $10 \mathrm{kHz}$ rf field strength $(58,59)$, and the $3 \mathrm{D}{ }^{15} \mathrm{~N}$-edited HMQCNOESY-HSQC spectrum with a $125 \mathrm{~ms}$ mixing time (60). A uniformly ${ }^{13} \mathrm{C}$ - and ${ }^{15} \mathrm{~N}$-labeled S100A4 sample was used to conduct the 3D CBCA(CO)NH (61,62), 3D HNCACB (63), 3D $\mathrm{HN}(\mathrm{CO}) \mathrm{CA}(64)$, and HNCA (65) triple-resonance NMR experiments. In all of the ${ }^{15} \mathrm{~N}$-edited experiments, the fast-HSQC detection scheme was incorporated into the sequence to avoid water saturation, and undesired magnetization was alleviated using pulsed field gradients throughout the various NMR pulse sequences (66).

\section{Thermodynamic Binding Studies}

Binding of $\mathrm{Ca}^{2+}$ and myosin-IIA peptides to apo-S100A4 and $\mathrm{Ca}^{2+}-\mathrm{S} 100 \mathrm{~A} 4$, respectively, was analyzed by measuring heat changes using a VP-ITC titration microcalorimeter (MicroCal, Inc., Northampton, MA). All protein, peptide, and metal solutions were degassed under vacuum and equilibrated at $37^{\circ} \mathrm{C}$ prior to titration. The sample cell $(1.4 \mathrm{~mL})$ contained $20 \mathrm{mM}$ Tris (pH 7.5), $20 \mathrm{mM} \mathrm{KCl}, 250 \mu \mathrm{M}$ TCEP, and $75 \mu \mathrm{M} \mathrm{S100A4}$ in the $\mathrm{Ca}^{2+}$ titrations with $c$ values ranging between 5 and 200. The S100A4-containing buffer described above was supplemented with $800 \mu \mathrm{M} \mathrm{CaCl}_{2}$ for titrations monitoring myosin-IIA peptide binding to $\mathrm{Ca}^{2+}{ }_{-} \mathrm{S} 100 \mathrm{~A} 4$. In all titrations, the reference cell contained water. Stock concentrations for injection of the titrant were $3 \mathrm{mM} \mathrm{CaCl}_{2}$ and $0.5 \mathrm{mM} \mathrm{MIIA}^{1893-1923}$, with all of the other buffer conditions matched to the sample. Solutions were injected in $5 \mu \mathrm{L}$ aliquots using the default injection rate of $10 \mathrm{~s}$ with a $360 \mathrm{~s}$ interval between injections, which allowed the trace to return to baseline before the next injection. The resulting titration curves were corrected for the protein-free buffer control and analyzed using the Origin for ITC software supplied by MicroCal.

Fluorescence anisotropy measurements were performed at $22{ }^{\circ} \mathrm{C}$ using a Fluoromax-3 spectrofluorometer (Jobin Yvon Inc.). Individual reaction mixtures $(200 \mu \mathrm{L})$ contained 100 nM FITC-MIIA ${ }^{1908-1923}$ and 0-30 $\mu$ M S100A4 dimer in $20 \mathrm{mM}$ Tris (pH 7.5), 150 or $20 \mathrm{mM}$ $\mathrm{KCl}, 1 \mathrm{mM}$ DTT, $0.02 \% \mathrm{NaN}_{3}$, and $0.5 \mathrm{mM} \mathrm{CaCl}_{2}$. Anisotropy was measured with excitation at $494 \mathrm{~nm}$ and emission at $516 \mathrm{~nm}$. Measurements were acquired at the magic angle corresponding to the angle of $55^{\circ}$ between the vectors of polarization of the excitation and emission light using a $G$ factor of 0.634 previously determined for FITC on this instrument. Competition assays with MIIA ${ }^{1893-1923}$ and MIIA ${ }^{1851-1960}$ contained $15 \mu \mathrm{M}$ S100A4 dimer, $100 \mathrm{nM}$ FITC-MIIA ${ }^{1908-1923}, 0.3 \mathrm{mM} \mathrm{CaCl}_{2}$, and $0-40$ and $0-30 \mu \mathrm{M}$ peptide, respectively, in $20 \mathrm{mM}$ Tris (pH 7.5), 150 or $20 \mathrm{mM} \mathrm{KCl,} 1 \mathrm{mM} \mathrm{DTT}, 0.02 \% \mathrm{NaN}_{3}$, and $0.5 \mathrm{mM} \mathrm{CaCl}_{2}$. Controls included experiments representing maximum anisotropy (15 $\mu \mathrm{M} \mathrm{S100A4}, 100 \mathrm{nM}$ FITC-MIIA ${ }^{1908-1923}$, and calcium) and minimum anisotropy (100 nM FITC-MIIA ${ }^{1908-1923}$ and calcium). Experiments were performed in triplicate and results fit to a sigmoidal doseresponse equation with a variable slope to obtain the $\mathrm{EC}_{50}$ value. Using this value, the dissociation constant for the peptides was obtained using the equation $\left.K_{\mathrm{d}}=K_{\mathrm{dP}} \mathrm{EC}_{50}\right) /[\mathrm{S}]$, where $\mathrm{EC}_{50}$ is the concentration at half-maximal binding of the competing peptide determined from fitting the raw data, $K_{\mathrm{dP}}$ is the dissociation constant for binding of FITCMIIA ${ }^{1908-1923}$ to S100A4, and [S] represents the concentration of S100A4 dimer.

$\mathrm{Ca}^{2+}$ binding affinities for $\mathrm{EF} 1$ and EF2 of S100A4 in the presence of myosin-IIA were determined using a 5,5' $\mathrm{Br}_{2}$-BAPTA competition assay as described previously (67). Calcium was titrated into a solution containing $25 \mu \mathrm{M} 5,5^{\prime} \mathrm{Br}_{2}-\mathrm{BAPTA}, 12.5 \mu \mathrm{M} \mathrm{S} 100 \mathrm{~A} 4$ dimer, and $125 \mu \mathrm{M}$ MIIA $^{1851-1960}$ at $25^{\circ} \mathrm{C}$ in $20 \mathrm{mM}$ Tris (pH 7.5), $150 \mathrm{mM} \mathrm{KCl}, 1 \mathrm{mM}$ DTT, and $0.02 \%$ $\mathrm{NaN}_{3}$, and the decrease in absorbance was monitored at $263 \mathrm{~nm}$. The total amount of $\mathrm{Ca}^{2+}$ in the protein preparation was less than $0.1 \mathrm{~mol}$ of $\mathrm{Ca}^{2+} / \mathrm{mol}$ of protein. Using Caligator, averaged 
data from five titrations from four independent experiments were fit to two $\mathrm{Ca}^{2+}$ binding sites using a stepwise macroscopic binding equation in the presence of chelator (68).

\section{Analytical Ultracentrifugation}

Sedimentation equilibrium and velocity experiments were performed with a Beckman XL-I analytical ultracentrifuge equipped with absorbance optics and a Ti60 rotor at $25{ }^{\circ} \mathrm{C}$. The sedimentation boundaries were monitored at $280 \mathrm{~nm}$. Wild-type and $\triangle 13 \mathrm{C} \mathrm{S100A4}$ were dialyzed into a buffer containing $20 \mathrm{mM}$ Tris ( $\mathrm{pH} 7.5$ ), $150 \mathrm{mM} \mathrm{KCl}, 1 \mathrm{mM}$ TCEP, $0.02 \%$ $\mathrm{NaN}_{3}$, and either $10 \mathrm{mM} \mathrm{CaCl}_{2}\left(\mathrm{Ca}^{2+}\right.$-bound) or $2 \mathrm{mM}$ EDTA and $2 \mathrm{mM} \mathrm{EGTA}\left(\mathrm{Ca}^{2+}\right.$-free). Sedimentation velocity experiments were conducted at $55000 \mathrm{rpm}$ using double-sector centerpieces. S100A4 subunit concentrations from 10 to $100 \mu \mathrm{M}$ were analyzed [DCDT+ version 2.0.9 (69)]. Sedimentation equilibrium experiments were conducted using six-channel centerpieces; three concentrations of protein were analyzed for each experiment (wild-type $\mathrm{Ca}^{2+}$-bound S100A4, 28, 54, and $74 \mu \mathrm{M}$; wild-type apo-S100A4, 23, 38, and $52 \mu \mathrm{M} ; \mathrm{Ca}^{2+}$

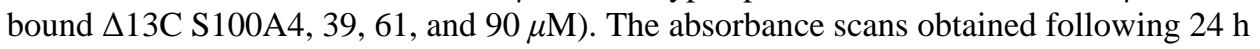
equilibrations at 15000 and $22000 \mathrm{rpm}$ were globally analyzed using HeteroAnalysis version 1.0.114 (J. L. Cole and J. W. Lary, Analytical Ultracentrifugation Facility, Biotechnology Services Center, University of Connecticut, Storrs, CT) for the weight-average molecular weight or the dimer-tetramer equilibrium constant. The $v$-bar values of 0.7346 and 0.7337 were calculated from the amino acid composition of wild-type S100A4 and $\triangle 13 \mathrm{C} \mathrm{S100A4,}$ respectively. Density and viscosity values were provided by Sednterp version 1.06 (B. Hayes, T. Laue, and J. Philo, Sedimentation Interpretation Program, 2003, University of New Hampshire, Durham, NH). The best-fit parameters and their 95\% joint confidence intervals are reported. The calculated masses of wild-type S100A4 and $\triangle 13 \mathrm{C}$ S100A4 monomers are 11597 and $9991.4 \mathrm{Da}$, respectively.

\section{RESULTS}

\section{$\mathrm{Ca}^{2+}$ binding to Apo-S100A4}

Like all S100 proteins, S100A4 has a pseudo-EF-hand (residues Ser20-Glu33; EF1) and a typical EF-hand (residues Asp63-Glu74; EF2). Since the interaction between S100A4 and target proteins such as MIIA depends on $\mathrm{Ca}^{2+}$ binding to the typical EF-hand, we examined the $\mathrm{Ca}^{2+}$ binding properties of S100A4 $(70,71)$. Under low-salt conditions used for NMR, human S100A4 binds two $\mathrm{Ca}^{2+}$ ions with the high-affinity site $\left(\mathrm{EF} 2\right.$; $\left.{ }^{\mathrm{Ca} 2} K_{\mathrm{d}}=3.3 \pm 1.3 \mu \mathrm{M}\right)$ exhibiting a dissociation constant that is 1 order of magnitude tighter than that of the lowaffinity site [EF1; ${ }^{\mathrm{Ca} 1} K_{\mathrm{d}}=54 \pm 11 \mu \mathrm{M}$ (Figure 1 and Table 1)]. As reported previously, at physiological salt levels the high-affinity site on S100A4 binds $\mathrm{Ca}^{2+}$ with a similar $K_{\mathrm{d}}$ $\left({ }^{\mathrm{Ca} 2} K_{\mathrm{d}}=2.6 \pm 1.0 \mu \mathrm{M}\right)$, but the pseudo-EF-hand shows no appreciable affinity for $\mathrm{Ca}^{2+}$ (70-73). At physiological salt levels in the presence of a myosin-IIA peptide (MIIA ${ }^{1851-1960}$ ), the $\mathrm{Ca}^{2+}$ binding affinity of S100A4 in both the pseudo-EF- and typical EFhands increases by more than 1 order of magnitude [ ${ }^{\mathrm{Ca} 1} K_{\mathrm{d}}=3.6 \pm 0.2 \mu \mathrm{M}$; ${ }^{\mathrm{Ca} 2} K_{\mathrm{d}}=0.26 \pm 0.01$ $\mu \mathrm{M}$ (Figure 1 and Table 1)].

To determine which amino acid residues in human S100A4 were most affected by $\mathrm{Ca}^{2+}$ binding in solution, $\mathrm{Ca}^{2+}$ titrations of human apo-S100A4 were monitored using NMR spectroscopic methods. Upon addition of $\mathrm{Ca}^{2+}$, most S100A4 resonances disappeared and then reappeared with new chemical shift values consistent with $\mathrm{Ca}^{2+}$ binding to S100A4 in the slow exchange regime on the NMR chemical shift time scale. In such a binding regime, the shifted correlations of $\mathrm{Ca}^{2+}-\mathrm{S} 100 \mathrm{~A} 4$ could not be followed during the titration and required that they be completely reassigned a priori. The largest of these chemical shift perturbations $(>900 \mathrm{~Hz})$ are clustered in the two EF-hand $\mathrm{Ca}^{2+}$-binding loops and in helix 4 (Figure 2), which is consistent with $\mathrm{Ca}^{2+}$ binding to both EF-hands. In addition to these largest perturbations, significant changes 
in chemical shift $(>200 \mathrm{~Hz}$ ) were observed for numerous other residues throughout the protein and support the notion that a significant conformational change occurs in human S100A4 upon binding $\mathrm{Ca}^{2+}$, as reported previously for murine S100A4 (74).

\section{Structure Determination}

Initial attempts to determine the S100A4 structure using molecular replacement methods with several existing NMR structures of S100 family members, including rat S100B (PDB entry 1DT7), rabbit S100A6 (PDB entry 1JWD) and human apo-S100A4 (PDB entry 1M31), were not successful. The excellent diffraction quality and relatively high symmetry of the S100A4 crystals suggested that sulfur SAD might be feasible. The four methionine residues, four cysteine residues, and two $\mathrm{Ca}^{2+}$ ions present in this 101-amino acid protein were expected to yield a significant anomalous signal when data were collected with $1.7 \AA$ radiation. Indeed, all four $\mathrm{Ca}^{2+}$ ions and most of the sulfur atoms in the asymmetric unit (containing two protein chains) were located with SHELXD (Figure 3A), allowing near-automated tracing of the entire structure (Figure 3B). In the final refined model, 92.0, 6.9, and 1.1\% of residues fall into the favorable, allowed, and generous areas of the Ramachandran plot, respectively (Table 2) (44). Residues with less favorable backbone conformations are located in the conformationally flexible loops of S100A4.

\section{Three-Dimensional Structure of $\mathrm{Ca}^{2+}-\mathrm{S} 100 \mathrm{~A} 4$}

Most of the crystallized S100A4 construct is well-defined in the experimental electron density map except for residues at the extreme C-terminus, Pro98-Lys101, which are not included in the model. Typical of the S100 family, each of the two S100A4 chains in the asymmetric unit is predominantly R-helical with four major helices per chain denoted H1-H4 (Figure 4A). As with other S100 protein family members, helices 1 and 4 from one subunit are arranged in an antiparallel manner with helices 1' and 4' of the second subunit to form an X-type four-helix bundle at the dimer interface. The two independent chains superimpose with a rms deviation of $0.71 \AA$ for all CR atoms with the most significant differences of $\sim 1.9 \AA$ residing in the conformationally flexible C-terminal tail (residues Phe89-Gln97).

Several $\mathrm{Ca}^{2+}{ }_{-} \mathrm{S} 100$ structures have been determined by X-ray crystallography and NMR (Table 3). A DALI search for homologous structures reveals that the most structurally similar dimeric S100 family member is human S100A6 with a $Z$ score of 15.1 and a rms deviation of $1.5 \AA$. The most significant structural differences between S100A4 and S100A6 occur in the hinge region between helices 2 and 3 (residues Leu42-Asp51). Interestingly, monomeric $\mathrm{Ca}^{2+}$ calbindin is also very similar to S100A4 with a $Z$ score of 11.7 and a rms deviation of $1.9 \AA$ (Table 3). The positions and orientations of helices 1-4 in the two proteins are comparable (Table 4) with the largest conformational difference of $\sim 12 \AA$ occurring in the hinge region. Notably, in calbindin, the relative orientations of helices 1 and 4 (crucial elements of the dimer interface in S100 proteins) are well preserved, even though the helices are significantly shorter than in S100A4.

The two S100A4 chains in the asymmetric unit interact to form a tight dimer with an interface that is observed throughout the S100 family. The dimer interface buries $3225 \AA^{2}$ of accessible surface area, $86 \%$ of which is contributed by helix 1 (residues Pro4-Ser20) and helix 4 (residues Phe72-Glu88) (Figure 4 and Table 5). There are a total of 34 residue-to-residue interchain contacts. Of these, 10 contacts are between helices 1 and 1', 12 contacts between helices 4 and $4^{\prime}$, and 12 contacts between helices 1 and $4^{\prime}$ and helices $1^{\prime}$ and 4 (Figure 4B). There are 12 hydrogen bonds within the dimer interface, some of which are asymmetric (Glu6 $\mathrm{O}_{\in 1}-\mathrm{Ser} 44^{\prime}$ $\mathrm{O}_{\gamma}$, Glu6 $\mathrm{O}_{\epsilon 2}-\operatorname{Ser} 44^{\prime} \mathrm{O}_{\gamma}$, Glu6 $\mathrm{O}_{\in 2}-\operatorname{Ser} 43^{\prime} \mathrm{N}$, His $17 \mathrm{~N}_{\epsilon 2}-\mathrm{Asn} 87^{\prime} \mathrm{O}_{\delta 1}$, and their symmetry mates). In addition, hydrogen bonds are observed between Ser80 $\mathrm{O}_{\gamma}$ and $\mathrm{Ser}^{\prime} 0^{\prime} \mathrm{O}_{\gamma}, \mathrm{Ser} 80 \mathrm{O}_{\gamma}$ and Ser44' N, Lys26 $\mathrm{N}_{\zeta}$ and Glu91' $\mathrm{O}_{\epsilon 1}$, and Lys26 $\mathrm{N}_{\zeta}$ and Glu91' $\mathrm{O}_{\epsilon 2}$. In homologous S100 
structures, the predominantly nonpolar nature of the subunit interface is conserved, but the actual degree of sequence conservation is low. For example, among four S100 structures with at least $48 \%$ overall sequence identity to S100A4 (Table 3) (75-78), only five of 23 interface residues $(21.7 \%)$ are conserved, indicating a higher than average level of sequence variability of the dimer interface in the S100 family.

\section{$\mathrm{Ca}^{2+}$ Coordination in S100A4}

Calcium ions bind to the pseudo-EF- and typical EF-hands at sites located between helices 1 and 2 and helices 3 and 4, respectively. In the pseudo-EF-hand, the $\mathrm{Ca}^{2+}$ ion is coordinated by the main chain carbonyl oxygens of Ser20, Glu23, Asp25, and Lys28; the side chain carboxylate of Glu33 (both oxygen atoms); and a water molecule (Figure 5A). Thus, the pseudo-EF-hand primarily coordinates $\mathrm{Ca}^{2+}$ with main chain carbonyl oxygen atoms. In the C-terminal typical EF-hand, the $\mathrm{Ca}^{2+}$ ion is coordinated by the side chains of Asp63, Asn65, Asp67, and Glu74 (both oxygen atoms); the carbonyl oxygen of Glu69; and a water molecule (Figure 5B). In both EF-hands, the $\mathrm{Ca}^{2+}$ ion is coordinated by seven oxygen atoms with average ion-oxygen distances of $2.4 \AA$, which is similar to those of other crystallographically determined S100 structures (Table 3). NMR and X-ray structures of related family members (e.g., S100B) show similar $\mathrm{Ca}^{2+}$ coordination in the typical EF-hand with contributions from carboxylate oxygen atoms in the $X, Y, Z,-Z$, and $-Z^{\prime}$ positions and from a backbone carbonyl oxygen in the $-Y$ position. The final coordination position $(-X)$ is occupied by a water molecule in the X-ray structure, which could not be observed experimentally by NMR. In contrast, the NMR structure of $\mathrm{Ca}^{2+}{ }_{-} \mathrm{S} 100 \mathrm{~B}$ and the $\mathrm{X}$-ray structure of $\mathrm{Ca}^{2+}-\mathrm{S} 100 \mathrm{~A} 4$ exhibit differences in $\mathrm{Ca}^{2+}$ coordination at the pseudo-EF-hand. Specifically, the NMR-based model, which relied heavily on lanthanide luminescence data (79), identified only four protein ligands and required modeling together with the NMR data to predict the $\mathrm{Ca}^{2+}$ ligands, whereas in the X-ray structures of $\mathrm{Ca}^{2+}{ }_{-} \mathrm{S} 100 \mathrm{~B}$ and $\mathrm{Ca}^{2+}-\mathrm{S} 100 \mathrm{~A} 4$, all seven protein ligands to oxygen are observed $(34,79)$. This discrepancy in $\mathrm{Ca}^{2+}$ coordination can be attributed to the high mobility exhibited by several regions of S100B in solution, which has been observed on multiple time scales using ${ }^{15} \mathrm{~N}$ relaxation NMR measurements for both S100B and S100A4 (80) (unpublished observations) and may account for why the pseudo-EF-hand binds $\mathrm{Ca}^{2+}$ more weakly than the typical EF-hand. In addition, despite identical coordination numbers and protein-ion distances, the reduced $\mathrm{Ca}^{2+}$ affinity exhibited by the pseudo-EF-hand may result from the required conformational adjustment of the four main chain carbonyl oxygen atoms within the pseudoEF-hand (81). These adjustments may be more energetically costly than positioning the more flexible side chains within the typical EF-hand.

\section{$\mathrm{Ca}^{2+}$ Switch in S100A4}

It is well-appreciated that $\mathrm{S} 100 \mathrm{~A} 4$ undergoes a $\mathrm{Ca}^{2+}$-dependent conformational rearrangement, which is required for the recognition and binding of its various protein targets (8). For the first time, this conformational change can be described at atomic resolution by comparing the structures of the apo and $\mathrm{Ca}^{2+}$-loaded forms of S100A4. Specifically, the interhelical angle between helices 3 and 4 in each subunit of apo-S100A4 is $162 \pm 2^{\circ}$, and in the $\mathrm{Ca}^{2+}$-bound state, it is $107 \pm 2^{\circ}$, indicating a $\mathrm{Ca}^{2+}$-dependent change of $-55^{\circ}$. Changes of $-63^{\circ}$ and $-49^{\circ}$ in the interhelical angles between helices 1 and 3 and helices 2 and 3, respectively, are observed as well (Figure 6A and Table 4). Accompanying these large helix movements are numerous reorientations of residues that are critical for coordination of $\mathrm{Ca}^{2+}$ (Figure 6B,C). Upon $\mathrm{Ca}^{2+}$ activation, helices 3 and 2 move most (55 and $-23^{\circ}$, respectively) whereas helices 1 and 4 move least $\left(1^{\circ}\right.$ and $12^{\circ}$, respectively) relative to their positions in the apo state. This is not surprising given that helices 1 and 4 are locked in the core of the dimer interface.

As a result of the reorientation of helix 3, the number of residue contacts between helices 3 and 4 decreases from four to three and the number of contacts between helices 3 and 2 increases 
from six to eight, including the formation of two new hydrogen bonds, Lys35-Glu52 and Lys31-Gln56. In addition, residues that line the peptide binding pocket in $\mathrm{Ca}^{2+}-\mathrm{S} 100 \mathrm{~A} 4$ are subject to dramatic shifts to achieve their productive binding conformation. For example, the side chain of Phe 45 moves $\sim 14 \AA$ from a solvent-exposed environment in apo-S100A4 to a location at the bottom of the binding pocket where it interacts with the side chain of Phe78 from helix 4. Leu46 which is buried in a hydrophobic cluster with residues Leu38, Leu42, Ile82, and Met85 in apo-S100A4 positions next to Leu38, Phe45, Ala54, Phe55, and Leu58. In the $\mathrm{Ca}^{2+}{ }_{-} \mathrm{S} 100 \mathrm{~A} 4$ dimer, the guanidinium group of Arg49 moves from a solvent-exposed position to the edge of the binding pocket to form a salt bridge with the carboxylate of Asp51. Lys57 moves away from Pro91 in apo-S100A4 to the edge of the pocket and forms a hydrogen bond with Asn61. In the $\mathrm{Ca}^{2+}-\mathrm{S} 100 \mathrm{~A} 4$ dimer, Asn61, Phe78, Cys81, and Met85 shift slightly to adjust to the new positions of the above-mentioned residues. These substantial side chain movements are consistent with the large chemical shift perturbations that are detected upon addition of $\mathrm{Ca}^{2+}$ in our NMR studies (Figure 2).

\section{Crystal Packing Interactions}

An examination of the crystal packing interactions shows that the C-terminal tail (residues Glu91-Gln97) of each S100A4 chain interacts with the deep cleft formed between helices 3 and 4 of the 2-fold crystallographically related molecule (Figure 7A). This pocket in other S100 proteins generally functions as the target recognition cleft. As a result of these interactions, a left-handed superhelix of S100A4 dimers is observed that runs parallel to the crystallographic $c$-axis (Figure 7B). Many of the interdimeric interactions between the C-terminal tail of one dimer and the target binding cleft of the symmetry related molecule are nonpolar, involving residues Glu91-Gln97 of the C-terminal tail and residues Phe45, Leu46, Arg49, Lys57, Asn61, Phe78, Cys81, and Met85 of the binding pocket (Figure 8). Of a total of 19 residue-to-residue contacts, only three are direct hydrogen bonds, and several more are indirect hydrogen bonds mediated by water molecules. The side chains of Glu91 and Asp95 exhibit weak density and relatively high $B$-factors, although they can be modeled to participate in potential ionic interactions with Arg49, Asn61, and Lys57, respectively, in the pocket. The most C-terminal residues (Pro98-Lys101) are not visible in the electron density map.

\section{Binding of the S100A4 C-Terminal Tail to $\mathrm{Ca}^{2+}-\mathrm{S} 100 \mathrm{~A} 4$}

To determine whether the packing interactions observed by X-ray crystallography between the $\mathrm{C}$-terminal tail and the peptide binding pocket also occur in solution, binding of a peptide derived from the C-terminus of S100A4 (residues Glu88-Lys101) was examined using NMR spectroscopy. In the absence of $\mathrm{Ca}^{2+}$, there were no chemical shift perturbations upon the addition of peptide; however, in the presence of $\mathrm{Ca}^{2+}$, perturbations in ${ }^{1} \mathrm{H}-{ }^{15} \mathrm{~N}$ correlations were observed (>40 Hz) for residues Val11, His17, Asn30, Glu36, Ala54, Phe55, Leu79, Ala83, Cys86, Phe89, Gly92, and Arg99 (Figure 9), which is consistent with this peptide binding to the target binding cleft of S100A4. The assignment of these resonances in the presence of peptide was straight-forward because peptide binding was in the fast exchange regime on the chemical shift time scale, which allowed the movements of the correlations to be followed easily. The perturbation of these specific residues is consistent with the interactions observed between dimer units of S100A4 in the X-ray crystal structure; however, peptide binding was weak with a $K_{\mathrm{d}}$ of $1.05 \pm 0.10 \mathrm{mM}$.

Analytical sedimentation studies were conducted to explore S100A4 oligomerization and whether the C-terminal tail mediates self-association. The weight-average molecular masses of $\mathrm{Ca}^{2+}$-bound S100A4, apo-S100A4, and $\mathrm{Ca}^{2+}$-bound $\triangle 13 \mathrm{C} \mathrm{S100A4}$ are $37429 \pm 2843,26710$ \pm 2773 , and $21969 \pm 1989 \mathrm{Da}$, respectively (Figure 10). The masses of S100A4 and $\Delta 13 \mathrm{C}$ S100A4 dimers calculated from their sequences are 23194 and $19983 \mathrm{Da}$, respectively. The correspondence of the calculated and observed molecular mass of $\mathrm{Ca}^{2+}$-bound $\triangle 13 \mathrm{C} \mathrm{S100A4}$ 
shows that it is dimeric at these protein concentrations. This conclusion was confirmed by sedimentation velocity analysis conducted as a function of $\triangle 13 \mathrm{C}$ S100A4 concentration. $S_{20, \mathrm{w}}$ linearly decreases with an increase in $\triangle 13 \mathrm{C}$ S100A 4 concentration as expected for a stable oligomer (data not shown).

In contrast, both apo and $\mathrm{Ca}^{2+}$-bound $\mathrm{S} 100 \mathrm{~A} 4$ dimers oligomerize to higher-order aggregates and $\mathrm{Ca}^{2+}$ facilitates this process. A dimer-tetramer reaction is the simplest association model that fits the data. $K_{\mathrm{d}}$ values of $19.84(7.85,41.27)$ and $469.4(194.20,1910.48) \mu \mathrm{M}$ were resolved for $\mathrm{Ca}^{2+}$-bound and apo-S100A4, respectively. These results were confirmed by sedimentation velocity analysis. $S_{20, w}$ linearly increases with an increase in S100A4 concentration (more so for the $\mathrm{Ca}^{2+}$-bound protein) as expected for a self-association reaction (data not shown). These observations indicate that the $\mathrm{C}$-terminal tail mediates oligomerization of the $\mathrm{Ca}^{2+}-\mathrm{S} 100 \mathrm{~A} 4$ dimer at high protein concentrations.

\section{Binding of Myosin-IIA to $\mathrm{Ca}^{2+}-\mathrm{S} 100 \mathrm{~A} 4$}

Next we examined S100A4 binding to peptides derived from the C-terminal coiled-coil domain of myosin-IIA that are monomeric and do not polymerize into filaments under any ionic strength. As found previously for myosin-IIA rods (MIIA $\left.{ }^{1338-1960}\right)(29)$, no interaction is observed between S100A4 and MIIA ${ }^{1908-1923}$, MIIA ${ }^{1893-1923}$, or MIIA ${ }^{1851-1960}$ in the absence of $\mathrm{Ca}^{2+}$, even at peptide and protein concentrations as high as $10^{-3} \mathrm{M}$ for MIIA ${ }^{1908-1923}$ and MIIA ${ }^{1893-1923}$. However, when $\mathrm{Ca}^{2+}$ is present, all of the constructs derived from the C-terminus of myosin-IIA bind S100A4 with relatively high affinity at either a low or physiological salt levels (Figure 11A,B and Table 6), confirming the $\mathrm{Ca}^{2+}$ dependence of the S100A4-MIIA interaction. For MIIA ${ }^{1908-1923}$, which comprises the minimal S100A4 binding site, the affinity is slightly higher $\left(K_{\mathrm{d}}=0.89 \pm 0.12 \mu \mathrm{M}\right)$ than for filamentous myosinIIA rods (MIIA $\left.{ }^{1338-1960} ; K_{\mathrm{d}}=2.7 \pm 0.6 \mu \mathrm{M}\right)$ under low-salt conditions $(20 \mathrm{mM} \mathrm{KCl})$. Similarly under low-salt conditions, $\mathrm{Ca}^{2+}-\mathrm{S} 100 \mathrm{~A} 4$ binds MIIA ${ }^{1893-1923}$ and MIIA ${ }^{1851-1960}$ with 6-8fold higher affinities than filamentous rods (MIIA $\left.{ }^{1338-1960}\right)$. Together, these data indicate that $\mathrm{Ca}^{2+}-\mathrm{S} 100 \mathrm{~A} 4$ binds to monomeric MIIA constructs more tightly than to polymeric MIIA rods. It should be noted that these comparisons were made under low-salt conditions because S100A4 depolymerizes MIIA rods under physiological conditions $(150 \mathrm{mM} \mathrm{KCl})(29)$.

We also examined binding of the MIIA peptides under physiological conditions $(150 \mathrm{mM} \mathrm{KCl})$ (Table 6). Specifically, $\mathrm{Ca}^{2+}{ }_{-}$S100A4 binds the largest of these MIIA constructs, MIIA ${ }^{1851-1960}$, with slightly higher affinity $\left(K_{\mathrm{d}}=0.50 \pm 0.01 \mu \mathrm{M}\right)$ than the smaller $\operatorname{MIIA}^{1893-1923}\left(K_{\mathrm{d}}=1.1 \pm 0.1 \mu \mathrm{M}\right)$ and MIIA ${ }^{1908-1923}\left(K_{\mathrm{d}}=1.7 \pm 0.2 \mu \mathrm{M}\right)$ peptides. The shorter peptides exhibit some salt dependence in their binding to S100A4, whereas salt concentration has no discernible effect on the binding of the larger peptide (MIIA ${ }^{1851-1960}$ ) (Table 6). Notably, these studies demonstrate that MIIA does not have to be in a filament or in a coiled-coil conformation to bind $\mathrm{Ca}^{2+}$-loaded S100A4.

\section{Mapping the Myosin-IIA Binding Site on $\mathrm{Ca}^{2+}-\mathrm{S} 100 \mathrm{~A} 4$}

A comparison of apo and $\mathrm{Ca}^{2+}$-bound S100A4 shows that there is a large rearrangement in the position of helix 3 , which exposes a hydrophobic pocket on $\mathrm{Ca}^{2+}-\mathrm{S} 100 \mathrm{~A} 4$ that is not accessible in apo-S100A4 (23) (Figure 4A). A similar $\mathrm{Ca}^{2+}$-dependent conformational change is required for other S100 proteins to bind their respective targets (34-36,82-84). Therefore, we used NMR spectroscopic methods to investigate the binding of MIIA ${ }^{1908-1923}$ to $\mathrm{Ca}^{2+}-\mathrm{S} 100 \mathrm{~A} 4$ to determine whether this pocket comprises the MIIA binding site.

During the titration of the MIIA ${ }^{1908-1923}$ peptide into $\mathrm{Ca}^{2+}{ }_{-}$S100A4, many of the resonances broadened and in some cases disappeared or reappeared, consistent with MIIA ${ }^{1908-1923}$ binding; however, all of the observable correlations could be assigned sequence specifically 
when the titration was complete (Figure 12). An analysis of chemical shifts, NOE correlations, and hydrogen exchange data $(85,86)$ demonstrates that very few changes in the secondary structure of $\mathrm{Ca}^{2+}$-bound S100A4 are observed upon binding of MIIA ${ }^{1908-1923}$ (data not shown). Thus, the chemical shift perturbation data could be used reliably to map the MIIA ${ }^{1908-1923}$ peptide binding site on $\mathrm{Ca}^{2+}-\mathrm{S} 100 \mathrm{~A} 4$. Unlike the transition from apo-S100A4 to holo-S100A4, in which nearly two-thirds of the resonances undergo large changes in chemical shift (Figure 13A), MIIA ${ }^{1908-1923}$ binding produces chemical shift perturbations smaller in magnitude. Following peptide addition, perturbations of amide ${ }^{1} \mathrm{H},{ }^{15} \mathrm{~N},{ }^{13} \mathrm{C}_{\alpha}$, and ${ }^{13} \mathrm{C}_{\beta}$ resonances (>75 Hz total per residue) occur for residues in helix 1 (Val11, Met12, Ser14, and Phe16), the pseudo-EF-hand (Ser20, Phe27, Lys28, and Asn30), the hinge (Glu41, Gly47, Lys48, Thr50, and Asp51), helix 3 (Ser60 and Leu62), the typical EF-hand (Asn68 and Val70), helix 4 (Phe78, Leu79, Met85, and Cys86), and the C-terminal tail (Gly92) of $\mathrm{Ca}^{2+}$ S100A4 when the MIIA ${ }^{1908-1923}$ peptide is added (Figure 13B). The changes in chemical shift for these specific residues are consistent with MIIA ${ }^{1908-1923}$ binding in a hydrophobic pocket of S100A4 that is exposed upon addition of $\mathrm{Ca}^{2+}$.

\section{DISCUSSION}

Our biochemical studies demonstrate that in the presence of target (e.g., a myosin-IIA peptide), the $\mathrm{Ca}^{2+}$ binding affinity of S100A4 in both EF-hands increases by more than 1 order of magnitude $\left(K_{\mathrm{d}}\right.$ values of 3.6 and $0.26 \mu \mathrm{M}$ for the pseudo-EF-hand and typical EF-hand, respectively, in the presence of MIIA $\left.{ }^{1851-1960}\right)$. These results with the human S100A4-MIIA complex are similar to observations with other S100 proteins $(82,87-89)$ and demonstrate that like other $\mathrm{Ca}^{2+}$-binding proteins (e.g., calmodulin) (90), S100 protein family members exhibit a higher affinity for $\mathrm{Ca}^{2+}$ in the presence of their target proteins. Target-induced tuning of $\mathrm{Ca}^{2+}$ affinities has important implications when considering S100 protein activation in vivo. Intracellular $\mathrm{Ca}^{2+}$ levels are tightly controlled, with quiescent cells exhibiting $\mathrm{Ca}^{2+}$ concentrations of $\sim 100 \mathrm{nM}$; however, local $\mathrm{Ca}^{2+}$ levels can rapidly and transiently increase to low micromolar levels (91-94). Thus, the increased $\mathrm{Ca}^{2+}$ binding affinities exhibited by S100A4 in the presence of the myosin-IIA peptide could tune S100A4 activation and inactivation in response to specific temporal and spatial cellular events.

Similar to the case for other $\mathrm{S} 100$ family members, $\mathrm{Ca}^{2+}$ binding has a dramatic effect on S100A4 conformation. Superimposition of the apo-S100A4 NMR structure and the $\mathrm{Ca}^{2+}$ bound S100A4 X-ray structure presented here reveals a large-scale rearrangement of the hinge region and helix 3. In apo-S100A4, helices 3 and 4 adopt a nearly antiparallel orientation relative to each other (helical angle of $162 \pm 4^{\circ}$ ), and this conformation is stabilized by multiple interactions between helix 3 and helices 2 and 4 . In contrast, in the $\mathrm{Ca}^{2+}$-bound S100A4 structure, the EF-hands change their conformation due to metal binding, which causes helix 2 and helix 3 to rotate relative to the almost immobile core formed by helices 1 and 4 . In the $\mathrm{Ca}^{2+}-\mathrm{S} 100 \mathrm{~A} 4$ structure, helix 3 is nearly orthogonal to helix 2 and helix 4 (helical angles of $102 \pm 2^{\circ}$ and $107 \pm 2^{\circ}$, respectively). This reorganization results in the formation of a cleft between helices 3 and 4 that is appropriately configured to accept target peptides such as those from myosin-IIA. The largest conformational transition occurs in the hinge region that together with helices 3 and 4 contributes to the target binding pocket.

Structural comparisons indicate that $\mathrm{Ca}^{2+}$ activation brings about similar conformational changes in S100A4, S100A1, S100A6, S100A11, S100A12, S100A13, and S100B in terms of overall structure and interhelical angles (23,34,35,75-78,95-99). Helices 1 and 4, which are locked in the dimer interface, are the most structurally conserved in both the apo and $\mathrm{Ca}^{2+}$ bound forms. Helices 2 and 3 and especially the hinge region deviate most among both apo and $\mathrm{Ca}^{2+}$-bound structures. Thus, conformational variability within the target binding pocket is likely to be important for target protein specificity within the S100 family. 
The C-terminal tail is the most flexible region in all S100 structures, as the observed conformations and orientations vary considerably in the structures listed in Table 3. On the basis of crystal lattice interactions, the current S100A4 structure suggests interdimer selfassociation. Interestingly, in the holmium-substituted S100A7 structure (100), the C-terminal tail self-associates with the binding pocket of the same S100 subunit via intramolecular interactions. The position of the peptide within the pocket is quite similar to that in S100A4; however, its contacts within the pocket and especially the structure of the hinge region are distinct.

To determine whether intermolecular interactions between S100A4 dimers can occur in solution, a 13mer peptide derived from the C-terminal tail of S100A4 (residues Pro98-Lys101) was titrated into dimeric $\mathrm{Ca}^{2+}-\mathrm{S} 100 \mathrm{~A} 4$. Although perturbations in both ${ }^{1} \mathrm{H}$ and ${ }^{15} \mathrm{~N}$ backbone resonances in $\mathrm{Ca}^{2+}-\mathrm{S} 100 \mathrm{~A} 4$ were detected in the hinge region and helix 4 and are consistent with interdimer interactions observed in the $\mathrm{X}$-ray structure, the affinity of this peptide is quite low for binding intact $\mathrm{Ca}^{2+}-\mathrm{S} 100 \mathrm{~A} 4\left(K_{\mathrm{d}}=1.05 \pm 0.10 \mathrm{mM}\right)$. However, sedimentation equilibrium studies indicate that at high S100A4 concentrations, full-length S100A4 can selfassociate into tetramers in a $\mathrm{Ca}^{2+}$-dependent manner. Moreover, assembly is mediated by the C-terminal tail as deletion of these residues results in the formation of a stable dimer. Notably, in normal and tumor cells, S100A4 dimer concentrations range from 3 to $5 \mu \mathrm{M}$, with concentrations as high as $10 \mu \mathrm{M}$ in some carcinoma cells (33) (unpublished observations). Given the magnitudes of the equilibrium constants governing formation of S100A4 tetramers, intracellular S100A4 is likely to be predominantly a dimer.

It is also notable that the structure of S100A4 crystallized in the presence of $\mathrm{Ca}^{2+}$ and PCP shows no indication of bound PCP; however, crystals could be obtained only in the presence of PCP. We propose that inhibitor binding in solution promotes an open conformation similar to those observed in other ternary S100 complexes $(84,101,102)$ and that the inhibitor exchanges for the C-terminal tail of the nascent S100A4 molecule, thus facilitating crystallization.

As with other S100 proteins, the interaction between S100A4 and the C-terminus of myosinIIA is dependent on a " $\mathrm{Ca}^{2+}$-switch" mechanism for binding. Our NMR studies demonstrate that the MIIA ${ }^{1908-1923}$ peptide binds in a $\mathrm{Ca}^{2+}$-induced hydrophobic pocket of S100A4 that is comprised of residues in the hinge region, helix 3, and helix 4 . These findings are consistent with other S100-target peptide complexes, including S100B-p53, S100B-NDR, S100BTRTK, S100A10-annexin II, and S100A11-annexin I complexes $(82,84,88,96,101,103)$; however, when compared among the S100 proteins, the residues comprising the pocket are not conserved. The low degree of sequence conservation between S100 homologues within the binding pocket suggests that this sequence divergence may provide a mechanism for target specific recognition and binding (104).

These studies demonstrate that S100A4 binds with high affinity to short MIIA peptides (e.g., MIIA ${ }^{1908-1923}$ ) and MIIA peptides that are predicted to form a coiled coil (e.g., MIIA $^{1893-1923}$ and MIIA ${ }^{1851-1960}$ ). Notably, a highly conserved 29-residue sequence, termed the assembly competence domain or ACD, was identified as a critical region for myosin-II assembly (30,31). The ACD and the sequences immediately flanking it have been termed the extended ACD (residues 1857-1919 in myosin-IIA) and are predicted to form a very stable coiled coil (30). Our previous studies demonstrate that the S100A4 binding site (residues 19081923) maps to the C-terminal end of the extended ACD on myosin-IIA (29). It is also important to note that nearly all S100-target complexes examined thus far show that each subunit in a S100 dimer binds to a single helical peptide $(84,101,102)$. On the basis of these observations, we propose that S100A4 promotes myosin-IIA filament disassembly by binding a single 
polypeptide chain of the coiled coil. This would allow for $\mathrm{Ca}^{2+}$-dependent conformational rearrangements that may result in partial unwinding of the coiled coil.

\section{ACKNOWLEDGMENT}

We thank Dr. Michael Brenowitz for assistance with analytical ultracentrifugation experiments and the staff of the X6A beamline at the National Synchrotron Light Source for the help. We acknowledge support from the Albert Einstein College of Medicine Cancer Center (National Cancer Institute Grant P30CA13330).

\section{REFERENCES}

1. Donato R. S100: A multigenic family of calcium-modulated proteins of the EF-hand type with intracellular and extracellular functional roles. Int. J. Biochem. Cell Biol 2001;33:637-668. [PubMed: 11390274]

2. Marenholz I, Heizmann CW, Fritz G. S100 proteins in mouse and man: From evolution to function and pathology (including an update of the nomenclature). Biochem. Biophys. Res. Commun 2004;322:1111-1122. [PubMed: 15336958]

3. Zimmer DB, Cornwall EH, Landar A, Song W. The S100 protein family: History, function, and expression. Brain Res. Bull 1995;37:417-429. [PubMed: 7620916]

4. Santamaria-Kisiel L, Rintala-Dempsey AC, Shaw GS. Calcium-dependent and -independent interactions of the S100 protein family. Biochem. J 2006;396:201-214. [PubMed: 16683912]

5. Grigorian MS, Tulchinsky EM, Zain S, Ebralidze AK, Kramerov DA, Kriajevska MV, Georgiev GP, Lukanidin EM. The mts1 gene and control of tumor metastasis. Gene 1993;135:229-238. [PubMed: 8276262]

6. Takenaga K, Nakamura Y, Sakiyama S. Cellular localization of pEL98 protein, an S100-related calcium binding protein, in fibroblasts and its tissue distribution analyzed by monoclonal antibodies. Cell Struct. Funct 1994;19:133-141. [PubMed: 7954872]

7. Helfman DM, Kim EJ, Lukanidin E, Grigorian M. The metastasis associated protein S100A4: Role in tumour progression and metastasis. Br. J. Cancer 2005;92:1955-1958. [PubMed: 15900299]

8. Garrett SC, Varney KM, Weber DJ, Bresnick AR. S100A4, a mediator of metastasis. J. Biol. Chem 2006;281:677-680. [PubMed: 16243835]

9. Rudland PS, Platt-Higgins A, Renshaw C, West CR, Winstanley JH, Robertson L, Barraclough R. Prognostic significance of the metastasis-inducing protein S100A4 (p9Ka) in human breast cancer. Cancer Res 2000;60:1595-1603. [PubMed: 10749128]

10. Gongoll S, Peters G, Mengel M, Piso P, Klempnauer J, Kreipe H, von Wasielewski R. Prognostic significance of calcium-binding protein S100A4 in colorectal cancer. Gastroenterology 2002;123:1478-1484. [PubMed: 12404222]

11. Davies BR, Donnell M, Durkan GC, Rudland PS, Barraclough R, Neal DE, Mellon JK. Expression of S100A4 protein is associated with metastasis and reduced survival in human bladder cancer. J. Pathol 2002;196:O-299.

12. Ninomiya I, Ohta T, Fushida S, Endo Y, Hashimoto T, Yagi M, Fujimura T, Nishimura G, Tani T, Shimizu K, Yonemura Y, Heizmann CW, Schafer BW, Sasaki T, Miwa K. Increased expression of S100A4 and its prognostic significance in esophageal squamous cell carcinoma. Int. J. Oncol 2001;18:715-720. [PubMed: 11251165]

13. Kimura K, Endo Y, Yonemura Y, Heizmann CW, Schafer BW, Watanabe Y, Sasaki T. Clinical significance of S100A4 and E-cadherin-related adhesion molecules in non-small cell lung cancer. Int. J. Oncol 2000;16:1125-1131. [PubMed: 10811984]

14. Cho YG, Nam SW, Kim TY, Kim YS, Kim CJ, Park JY, Lee JH, Kim HS, Lee JW, Park CH, Song YH, Lee SH, Yoo NJ, Lee JY, Park WS. Overexpression of S100A4 is closely related to the aggressiveness of gastric cancer. APMIS 2003;111:539-545. [PubMed: 12887505]

15. Hernan R, Fasheh R, Calabrese C, Frank AJ, Maclean KH, Allard D, Barraclough R, Gilbertson RJ. ERBB2 up-regulates S100A4 and several other prometastatic genes in medulloblastoma. Cancer Res 2003;63:140-148. [PubMed: 12517790] 
16. Rosty C, Ueki T, Argani P, Jansen M, Yeo CJ, Cameron JL, Hruban RH, Goggins M. Overexpression of S100A4 in pancreatic ductal adenocarcinomas is associated with poor differentiation and DNA hypomethylation. Am. J. Pathol 2002;160:45-50. [PubMed: 11786397]

17. Saleem M, Adhami VM, Ahmad N, Gupta S, Mukhtar H. Prognostic significance of metastasisassociated protein S100A4 (Mts1) in prostate cancer progression and chemoprevention regimens in an autochthonous mouse model. Clin. Cancer Res 2005;11:147-153. [PubMed: 15671539]

18. Zou M, Al-Baradie RS, Al-Hindi H, Farid NR, Shi Y. S100A4 (Mts1) gene overexpression is associated with invasion and metastasis of papillary thyroid carcinoma. Br. J. Cancer 2005;93:12771284. [PubMed: 16265347]

19. Stein U, Arlt F, Walther W, Smith J, Waldman T, Harris ED, Mertins SD, Heizmann CW, Allard D, Birchmeier W, Schlag PM, Shoemaker RH. The metastasis-associated gene S100A4 is a novel target of -catenin/T-cell factor signaling in colon cancer. Gastroenterology 2006;131:1486-1500. [PubMed: 17101323]

20. Fearon ER, Vogelstein B. A genetic model for colorectal tumorigenesis. Cell 1990;61:759-767. [PubMed: 2188735]

21. Bienz M, Clevers H. Linking colorectal cancer to Wnt signaling. Cell 2000;103:311-320. [PubMed: 11057903]

22. Polakis P. The many ways of Wnt in cancer. Curr. Opin. Genet. Dev 2007;17:45-51. [PubMed: 17208432]

23. Vallely KM, Rustandi RR, Ellis KC, Varlamova O, Bresnick AR, Weber DJ. Solution structure of human mts1 (S100A4) as determined by NMR spectroscopy. Biochemistry 2002;41:12670-12680. [PubMed: 12379109]

24. Kriajevska MV, Cardenas MN, Grigorian MS, Ambartsumian NS, Georgiev GP, Lukanidin EM. Non-muscle myosin heavy chain as a possible target for protein encoded by metastasis-related mts-1 gene. J. Biol. Chem 1994;269:19679-19682. [PubMed: 8051043]

25. Ford HL, Silver DL, Kachar B, Sellers JR, Zain SB. Effect of Mts1 on the structure and activity of nonmuscle myosin II. Biochemistry 1997;36:16321-16327. [PubMed: 9405067]

26. Takenaga K, Nakamura Y, Sakiyama S, Hasegawa Y, Sato K, Endo H. Binding of pEL98 protein, an S100-related calcium-binding protein, to nonmuscle tropomyosin. J. Cell Biol 1994;124:757-768. [PubMed: 8120097]

27. Watanabe Y, Usada N, Minami H, Morita T, Tsugane S, Ishikawa R, Kohama K, Tomida Y, Hidaka $\mathrm{H}$. Calvasculin, as a factor affecting the microfilament assemblies in rat fibroblasts transfected by src gene. FEBS Lett 1993;324:51-55. [PubMed: 8504859]

28. Kriajevska M, Fischer-Larsen M, Moertz E, Vorm O, Tulchinsky E, Grigorian M, Ambartsumian N, Lukanidin E. Liprin 1, a member of the family of LAR transmembrane tyrosine phosphataseinteracting proteins, is a new target for the metastasis-associated protein S100A4 (Mts1). J. Biol. Chem 2002;277:5229-5235. [PubMed: 11836260]

29. Li ZH, Spektor A, Varlamova O, Bresnick AR. Mts1 regulates the assembly of nonmuscle myosinIIA. Biochemistry 2003;42:14258-14266. [PubMed: 14640694]

30. Sohn RL, Vikstrom KL, Strauss M, Cohen C, SzentGyorgyi AG, Leinwand LA. A 29 residue region of the sarcomeric myosin rod is necessary for filament formation. J. Mol. Biol 1997;266:317-330. [PubMed: 9047366]

31. Cohen C, Parry DA. A conserved C-terminal assembly region in paramyosin and myosin rods. J. Struct. Biol 1998;122:180-187. [PubMed: 9724619]

32. Dulyaninova NG, Malashkevich VN, Almo SC, Bresnick AR. Regulation of myosin-IIA assembly and Mts1 binding by heavy chain phosphorylation. Biochemistry 2005;44:6867-6876. [PubMed: 15865432]

33. Li ZH, Bresnick AR. The S100A4 metastasis factor regulates cellular motility via a direct interaction with myosin-IIA. Cancer Res 2006;66:5173-5180. [PubMed: 16707441]

34. Drohat AC, Baldisseri DM, Rustandi RR, Weber DJ. Solution structure of calcium-bound rat S100B $(\beta \beta)$ as determined by nuclear magnetic resonance spectroscopy. Biochemistry 1998;37:2729-2740. [PubMed: 9485423] 
35. Wright NT, Varney KM, Ellis KC, Markowitz J, Gitti RK, Zimmer DB, Weber DJ. The threedimensional solution structure of $\mathrm{Ca}^{2+}$-bound S100A1 as determined by NMR spectroscopy. J. Mol. Biol 2005;353:410-426. [PubMed: 16169012]

36. Sastry M, Ketchem RR, Crescenzi O, Weber C, Lubienski MJ, Hidaka H, Chazin WJ. The threedimensional structure of $\mathrm{Ca}^{2+}$-bound calcyclin: Implications for $\mathrm{Ca}^{2+}$-signal transduction by $\mathrm{S} 100$ proteins. Structure 1998;6:223-231. [PubMed: 9519412]

37. Otwinowski W, Minor F. Processing of X-ray diffraction data collected in oscillation mode. Methods Enzymol 1997;276:307-326.

38. Collaborative Computational Project Number 4. The CCP4 suite: Programs for protein crystallography. Acta Crystallogr 1994;D50:760-763.

39. Schneider TR, Sheldrick GM. Substructure solution with SHELXD. Acta Crystallogr 2002;D58:1772-1779.

40. Sheldrick GM. Macromolecular phasing with SHELXE. Z. Kristallogr 2002;217:644-650.

41. Lamzin, VS.; Perrakis, A.; Wilson, KS. International Tables for Crystallography: The ARP/WARP suite for automated construction and refinement of protein models. Kluwer Academic Publishers; Dordrecht, The Netherlands: 2001. Volume F: Crystallography of biological macromolecules.

42. Emsley P, Cowtan K. Coot: Model-building tools for molecular graphics. Acta Crystallogr 2004;D60:2126-2132.

43. Hooft RW, Vriend G, Sander C, Abola EE. Errors in protein structures. Nature 1996;381

44. Laskowski R, MacArthur M, Moss D, Thornton J. PROCHECK: A program to check the stereochemical quality of protein structures. J. Appl. Crystallogr 1993;26:283-291.

45. Krissinel E, Henrick K. Secondary-structure matching (SSM), a new tool for fast protein structure alignment in three dimensions. Acta Crystallogr 2004;D60:2256-2268.

46. Holm L, Sander C. Mapping the protein universe. Science 1996;273:595-603. [PubMed: 8662544]

47. Holm L, Park J. DaliLite workbench for protein structure comparison. Bioinformatics 2000;16:566567. [PubMed: 10980157]

48. Yap KL, Ames JB, Swindells MB, Ikura M. Vector geometry mapping. A method to characterize the conformation of helix-loop-helix calcium-binding proteins. Methods Mol. Biol 2002;173:317-324. [PubMed: 11859772]

49. Marion D, Ikura M, Tschudin R, Bax A. Rapid recording of 2d NMR-spectra without phase cycling: Application to the study of hydrogen-exchange in proteins. J. Magn. Reson 1989;85:393-399.

50. Delaglio F, Grzesiek S, Vuister GW, Zhu G, Pfeifer J, Bax A. NMRPipe: A multidimensional spectral processing system based on UNIX pipes. J. Biomol. NMR 1995;6:277-293. [PubMed: 8520220]

51. Zhu GA, Bax A. 2-Dimensional linear prediction for signals truncated in both dimensions. J. Magn. Reson 1992;98:192-199.

52. Zhu G, Bax A. Improved linear prediction for truncated signals of known phase. J. Magn. Reson 1990;90:405-410.

53. Live DH, Davis D, Agosta W, Cowburn D. Long range hydrogen bond mediated effects in peptides: Nitrogen-15 NMR study of gramicidin S in water and organic solvents. J. Am. Chem. Soc 1984;106:1939-1941.

54. Spera S, Bax A. Empirical correlation between protein backbone conformation and C- $\alpha$ and C- $\beta$ C- 13 nuclear-magnetic-resonance chemical-shifts. J. Am. Chem. Soc 1991;113:5490-5492.

55. Edison AS, Abildgaard F, Westler WM, Mooberry ES, Markley JL. Practical introduction to theory and implementation of multinuclear, multidimensional nuclear magnetic resonance experiments. Methods Enzymol 1994;239:3-79. [PubMed: 7830587]

56. Mori S, Abeygunawardana C, Johnson MO, van Zijl PC. Improved sensitivity of HSQC spectra of exchanging protons at short interscan delays using a new fast HSQC (FHSQC) detection scheme that avoids water saturation. J. Magn. Reson., Ser. B 1995;108:94-98. [PubMed: 7627436]

57. Kay L, Marion D, Bax A. J. Magn. Reson 1989;84:72-84.

58. Bax A, Davis D. J. Magn. Reson 1985;65:355-360.

59. Cavanagh J, Rance M. Suppression of cross-relaxation effects in Tocsy spectra via a modified dipsi-2 mixing sequence. J. Magn. Reson 1992;96:670-678. 
60. Ikura M, Bax A, Clore GM, Gronenborn AM. Detection of nuclear overhauser effects between degenerate amide proton resonances by heteronuclear 3-dimensional nuclear-magnetic-resonance spectroscopy. J. Am. Chem. Soc 1990;112:9020-9022.

61. Grzesiek S, Bax A. An efficient experiment for sequential backbone assignment of medium-sized isotopically enriched proteins. J. Magn. Reson 1992;99:201-207.

62. Muhandiram DR, Xu GY, Kay LE. An enhanced-sensitivity pure absorption gradient 4d N-15, C-13edited noesy experiment. J. Biomol. NMR 1993;3:463-470.

63. Wittekind M, Mueller L. Hncacb, a high-sensitivity 3d NMR experiment to correlate amide-proton and nitrogen resonances with the $\alpha$-carbon and $\beta$-carbon resonances in proteins. J. Magn. Reson., Ser. B 1993;101:201-205.

64. Grzesiek S, Bax A. Improved 3d triple-resonance NMR techniques applied to a 31-kDa protein. J. Magn. Reson 1992;96:432-440.

65. Yamazaki T, Lee W, Revington M, Mattiello DL, Dahlquist FW, Arrowsmith CH, Kay LE. An Hnca pulse scheme for the backbone assignment of N-15,C-13,H-2-labeled proteins: Application to a 37kDa Trp repressor DNA complex. J. Am. Chem. Soc 1994;116:6464-6465.

66. Bax A, Pochapsky SS. Optimized recording of heteronuclear multidimensional NMR-spectra using pulsed field gradients. J. Magn. Reson 1992;99:638-643.

67. Linse S. Calcium binding to proteins studied via competition with chromophoric chelators. Methods Mol. Biol 2002;173:15-24. [PubMed: 11859758]

68. Andre I, Linse S. Measurement of $\mathrm{Ca}^{2+}$-binding constants of proteins and presentation of the CaLigator software. Anal. Biochem 2002;305:195-205. [PubMed: 12054448]

69. Philo JS. Improved methods for fitting sedimentation coefficient distributions derived by timederivative techniques. Anal. Biochem 2006;354:238-246. [PubMed: 16730633]

70. Dukhanina EA, Dukhanin AS, Lomonosov MY, Lukanidin EM, Georgiev GP. Spectral studies on the calcium-binding properties of Mts 1 protein and its interaction with target protein. FEBS Lett 1997;410:403-406. [PubMed: 9237671]

71. Garrett SC, Hodgson L, Rybin A, Toutchkine A, Hahn KM, Lawrence DS, Bresnick AR. A biosensor of S100A4 metastasis factor activation: Inhibitor screening and cellular activation dynamics. Biochemistry 2008;47:986-996. [PubMed: 18154362]

72. Gibbs FE, Wilkinson MC, Rudland PS, Barraclough R. Interactions in vitro of p9Ka, the rat S-100related, metastasis-inducing, calcium-binding protein. J. Biol. Chem 1994;269:18992-18999. [PubMed: 8034656]

73. Pedrocchi M, Schafer BW, Durussel I, Cox JA, Heizmann CW. Purification and characterization of the recombinant human calcium-binding S100 proteins CAPL and CACY. Biochemistry 1994;33:6732-6738. [PubMed: 8204608]

74. Dutta K, Cox CJ, Huang H, Basavappa R, Pascal SM. Calcium coordination studies of the metastatic Mts1 protein. Biochemistry 2002;41:4239-4245. [PubMed: 11914069]

75. Maler L, Potts BC, Chazin WJ. High resolution solution structure of apo calcyclin and structural variations in the S100 family of calcium-binding proteins. J. Biomol. NMR 1999;13:233-247. [PubMed: 10212984]

76. Otterbein LR, Kordowska J, Witte-Hoffmann C, Wang CL, Dominguez R. Crystal structures of S100A6 in the $\mathrm{Ca}^{2+}$-free and $\mathrm{Ca}^{2+}$-bound states: The calcium sensor mechanism of $\mathrm{S} 100$ proteins revealed at atomic resolution. Structure 2002;10:557-567. [PubMed: 11937060]

77. Rustandi RR, Baldisseri DM, Inman KG, Nizner P, Hamilton SM, Landar A, Landar A, Zimmer DB, Weber DJ. Three-dimensional solution structure of the calcium-signaling protein apo-S100A1 as determined by NMR. Biochemistry 2002;41:788-796. [PubMed: 11790100]

78. Drohat AC, Amburgey JC, Abildgaard F, Starich MR, Baldisseri D, Weber DJ. Solution structure of rat apo-S100B $(\beta \beta)$ as determined by NMR spectroscopy. Biochemistry 1996;35:11577-11588. [PubMed: 8794737]

79. Chaudhuri D, Horrocks WD Jr. Amburgey JC, Weber DJ. Characterization of lanthanide ion binding to the EF-hand protein S100 $\beta$ by luminescence spectroscopy. Biochemistry 1997;36:9674-9680. [PubMed: 9245399] 
80. Inman KG, Baldisseri DM, Miller KE, Weber DJ. Backbone dynamics of the calcium-signaling protein apoS100B as determined by ${ }^{15}$ N NMR relaxation. Biochemistry 2001;40:3439-3448. [PubMed: 11297409]

81. Linse S, Brodin P, Johansson C, Thulin E, Grundstrom T, Forsen S. The role of protein surface charges in ion binding. Nature 1988;335:651-652. [PubMed: 3173484]

82. Rustandi RR, Drohat AC, Baldisseri DM, Wilder PT, Weber DJ. The $\mathrm{Ca}^{2+}$-dependent interaction of $\operatorname{S100B}(\beta \beta)$ with a peptide derived from $\mathrm{p} 53$. Biochemistry 1998;37:1951-1960. [PubMed: 9485322]

83. Weber, DJ.; Rustandi, R.; Carrier, F.; Zimmer, DB. Calcium: The molecular basis of calcium action in biology and medicine. Kluwer Academic Publishers; Dordrecht, The Netherlands: 2000.

Interaction of dimeric $\mathrm{S} 100 \mathrm{~B}(\beta \beta)$ with the tumor suppressor protein: A model for Ca-dependent S100target protein interactions; p. 469-487.

84. Inman KG, Yang R, Rustandi RR, Miller KE, Baldisseri DM, Weber DJ. Solution NMR structure of S100B bound to the high-affinity target peptide TRTK-12. J. Mol. Biol 2002;324:1003-1014. [PubMed: 12470955]

85. Wuthrich, K. NMR of proteins and nucleic acids. John Wiley; New York: 1986.

86. Wishart DS, Sykes BD. The C-13 chemical-shift index: A simple method for the identification of protein secondary structure using C-13 chemical-shift data. J. Biomol. NMR 1994;4:171-180. [PubMed: 8019132]

87. Kordowska J, Stafford WF, Wang CL. $\mathrm{Ca}^{2+}$ and $\mathrm{Zn}^{2+}$ bind to different sites and induce different conformational changes in human calcyclin. Eur. J. Biochem 1998;253:57-66. [PubMed: 9578461]

88. Rustandi RR, Baldisseri DM, Drohat AC, Weber DJ. Structural changes in the C-terminus of $\mathrm{Ca}^{2+}$ bound rat $\mathrm{S} 100 \mathrm{~B}(\beta \beta)$ upon binding to a peptide derived from the C-terminal regulatory domain of $\mathrm{p}$ 53. Protein Sci 1999;8:1743-1751. [PubMed: 10493575]

89. Markowitz J, Rustandi RR, Varney KM, Wilder PT, Udan R, Wu SL, Horrocks WD, Weber DJ. Calcium-binding properties of wild-type and EF-hand mutants of S100B in the presence and absence of a peptide derived from the C-terminal negative regulatory domain of $\mathrm{p} 53$. Biochemistry 2005;44:7305-7314. [PubMed: 15882069]

90. Peersen OB, Madsen TS, Falke JJ. Intermolecular tuning of calmodulin by target peptides and proteins: Differential effects on $\mathrm{Ca}^{2+}$ binding and implications for kinase activation. Protein Sci 1997;6:794-807. [PubMed: 9098889]

91. Lee J, Ishihara A, Oxford G, Johnson B, Jacobson K. Regulation of cell movement is mediated by stretch-activated calcium channels. Nature 1999;400:382-386. [PubMed: 10432119]

92. Berridge MJ, Lipp P, Bootman MD. The versatility and universality of calcium signalling. Nat. Rev. Mol. Cell Biol 2000;1:11-21. [PubMed: 11413485]

93. Kindzelskii AL, Petty HR. Intracellular calcium waves accompany neutrophil polarization, formylmethionylleucylphenylalanine stimulation, and phagocytosis: A high speed microscopy study. J. Immunol 2003;170:64-72. [PubMed: 12496384]

94. Clapham DE. Calcium signaling. Cell 2007;131:1047-1058. [PubMed: 18083096]

95. Dempsey AC, Walsh MP, Shaw GS. Unmasking the annexin I interaction from the structure of ApoS100A11. Structure 2003;11:887-897. [PubMed: 12842051]

96. Rety S, Osterloh D, Arie JP, Tabaries S, Seeman J, Russo-Marie F, Gerke V, Lewit-Bentley A. Structural basis of the $\mathrm{Ca}^{2+}$-dependent association between S100C (S100A11) and its target, the Nterminal part of annexin I. Structure 2000;8:175-184. [PubMed: 10673436]

97. Arnesano F, Banci L, Bertini I, Fantoni A, Tenori L, Viezzoli MS. Structural interplay between calcium(II) and copper(II) binding to S100A13 protein. Angew. Chem., Int. Ed 2005;44:6341-6344.

98. Li M, Zhang PF, Pan XW, Chang WR. Crystal structure study on human S100A13 at 2.0 A resolution. Biochem. Biophys. Res. Commun 2007;356:616-621. [PubMed: 17374362]

99. Maler L, Sastry M, Chazin WJ. A structural basis for S100 protein specificity derived from comparative analysis of apo and $\mathrm{Ca}^{2+}$-calcyclin. J. Mol. Biol 2002;317:279-290. [PubMed: 11902843]

100. Brodersen DE, Etzerodt M, Madsen P, Celis JE, Thogersen HC, Nyborg J, Kjeldgaard M. EF-hands at atomic resolution: The structure of human psoriasin (S100A7) solved by MAD phasing. Structure 1998;6:477-489. [PubMed: 9562557] 
101. Rety S, Sopkova J, Renouard M, Osterloh D, Gerke V, Tabaries S, Russo-Marie F, Lewit-Bentley A. The crystal structure of a complex of p11 with the annexin II N-terminal peptide. Nat. Struct. Biol 1999;6:89-95. [PubMed: 9886297]

102. Rustandi RR, Baldisseri DM, Weber DJ. Structure of the negative regulatory domain of $\mathrm{p} 53$ bound to $\mathrm{S} 100 \mathrm{~B}(\beta \beta)$. Nat. Struct. Biol 2000;7:570-574. [PubMed: 10876243]

103. Bhattacharya S, Large E, Heizmann CW, Hemmings B, Chazin WJ. Structure of the $\mathrm{Ca}^{2+} / \mathrm{S} 100 \mathrm{~B} /$ NDR kinase peptide complex: Insights into S100 target specificity and activation of the kinase. Biochemistry 2003;42:14416-14426. [PubMed: 14661952]

104. Kligman D, Hilt DC. The S100 protein family. Trends Biochem. Sci 1988;13:437-443. [PubMed: 3075365]

105. Ishikawa K, Nakagawa A, Tanaka I, Suzuki M, Nishihira J. The structure of human MRP8, a member of the $\mathrm{S} 100$ calcium-binding protein family, by MAD phasing at $1.9 \AA$ resolution. Acta Crystallogr 2000;D56:559-566.

106. Itou H, Yao M, Fujita I, Watanabe N, Suzuki M, Nishihira J, Tanaka I. The crystal structure of human MRP14 (S100A9), a Ca ${ }^{2+}$-dependent regulator protein in inflammatory process. J. Mol. Biol 2002;316:265-276. [PubMed: 11851337]

107. Moroz OV, Antson AA, Murshudov GN, Maitland NJ, Dodson GG, Wilson KS, Skibshoj I, Lukanidin EM, Bronstein IB. The three-dimensional structure of human S100A12. Acta Crystallogr 2001;D57:20-29.

108. Svensson LA, Thulin E, Forsen S. Proline cistrans isomers in calbindin D9k observed by X-ray crystallography. J. Mol. Biol 1992;223:601-606. [PubMed: 1542107] 
A

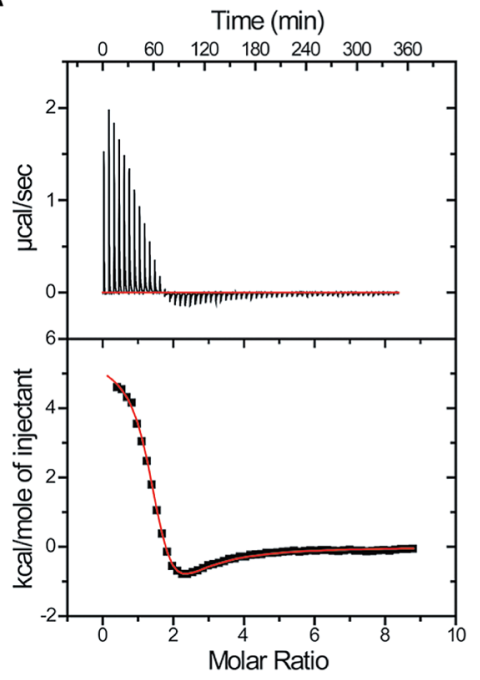

B

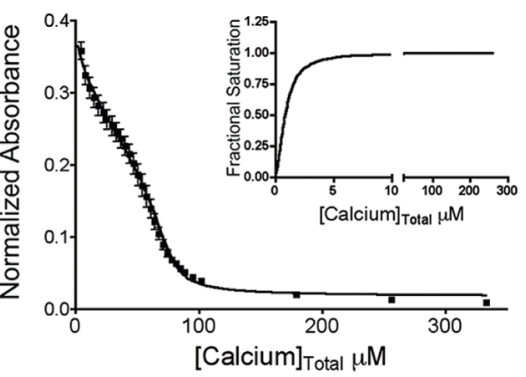

Figure 1.

Thermodynamic data showing $\mathrm{Ca}^{2+}$ binding to S100A4. (A) Isothermal titration calorimetry (ITC) data demonstrating the interaction of $\mathrm{S} 100 \mathrm{~A} 4$ with $\mathrm{Ca}^{2+}(n=2)$. (B) Competition assay with the chelator $5,5^{\prime} \mathrm{Br}_{2}$-BAPTA to examine the affinity of S100A4 for $\mathrm{Ca}^{2+}$ in the presence of MIIA ${ }^{1851-1960}$. The decrease in absorbance was monitored at $263 \mathrm{~nm}$ for a mixture

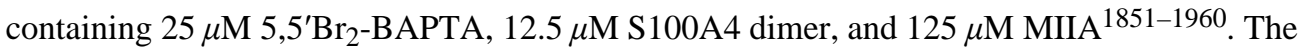
inset shows the saturation curve representation for the best fit in Caligator. 

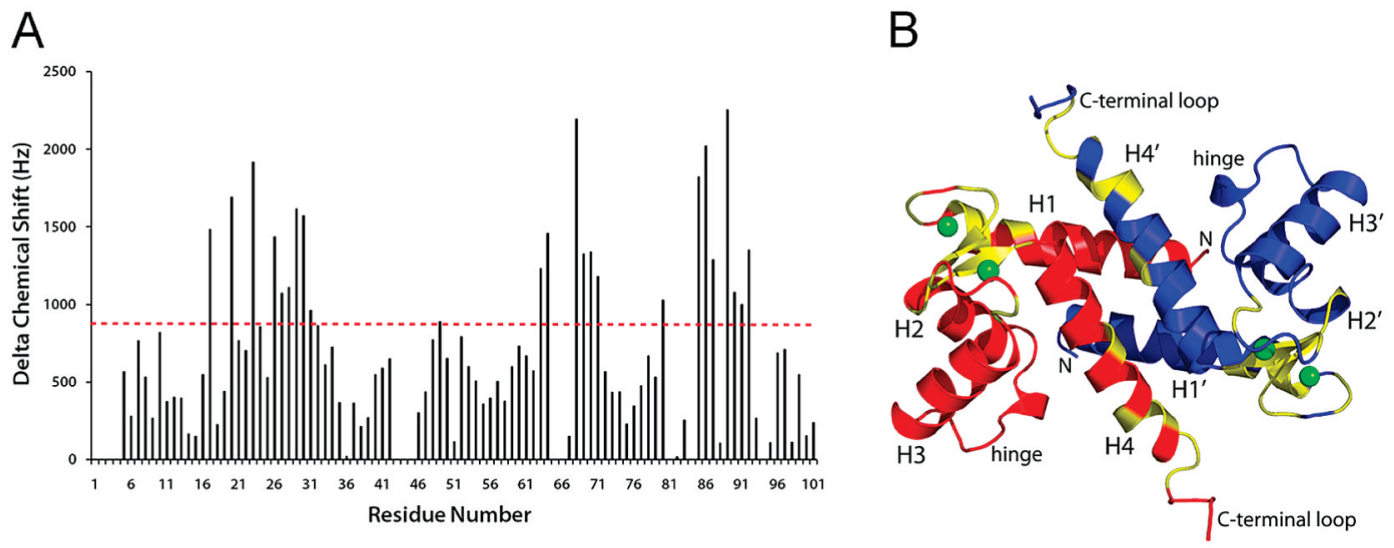

Figure 2.

Chemical shift perturbations following the addition of $\mathrm{Ca}^{2+}$ to apo-S100A4. (A) Bar graph of the cumulative ${ }^{1} \mathrm{H},{ }^{15} \mathrm{~N}$, and ${ }^{13} \mathrm{C}$ chemical shift perturbations observed per residue upon the addition of $\mathrm{Ca}^{2+}$ to apo-S100A4. (B) Ribbon diagram of $\mathrm{Ca}^{2+}-\mathrm{S} 100 \mathrm{~A} 4$ showing the subunits in red and blue. Residues highlighted in yellow exhibited the largest perturbations (as per the dashed red line at $900 \mathrm{~Hz}$ in panel A). 
A

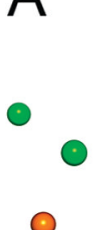

$\odot$
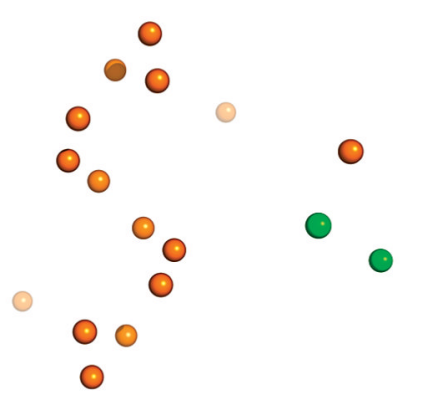

B

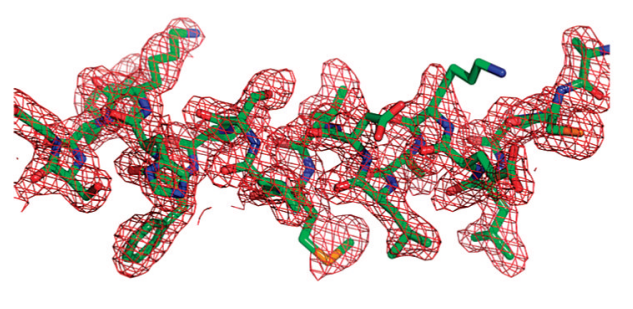

Figure 3.

(A) Heavy atom positions detected by SHELXD based on the SAD signal at $1.7 \AA$ wavelength. Green and orange spheres denote $\mathrm{Ca}^{2+}$ ions and sulfur atoms, respectively. (B) Refined model of S100A4 (residues Ala2-Gly21) superimposed onto the $2 F_{\mathrm{o}}-F_{\mathrm{c}}$ electron density map, contoured at $1 \sigma$. 
A
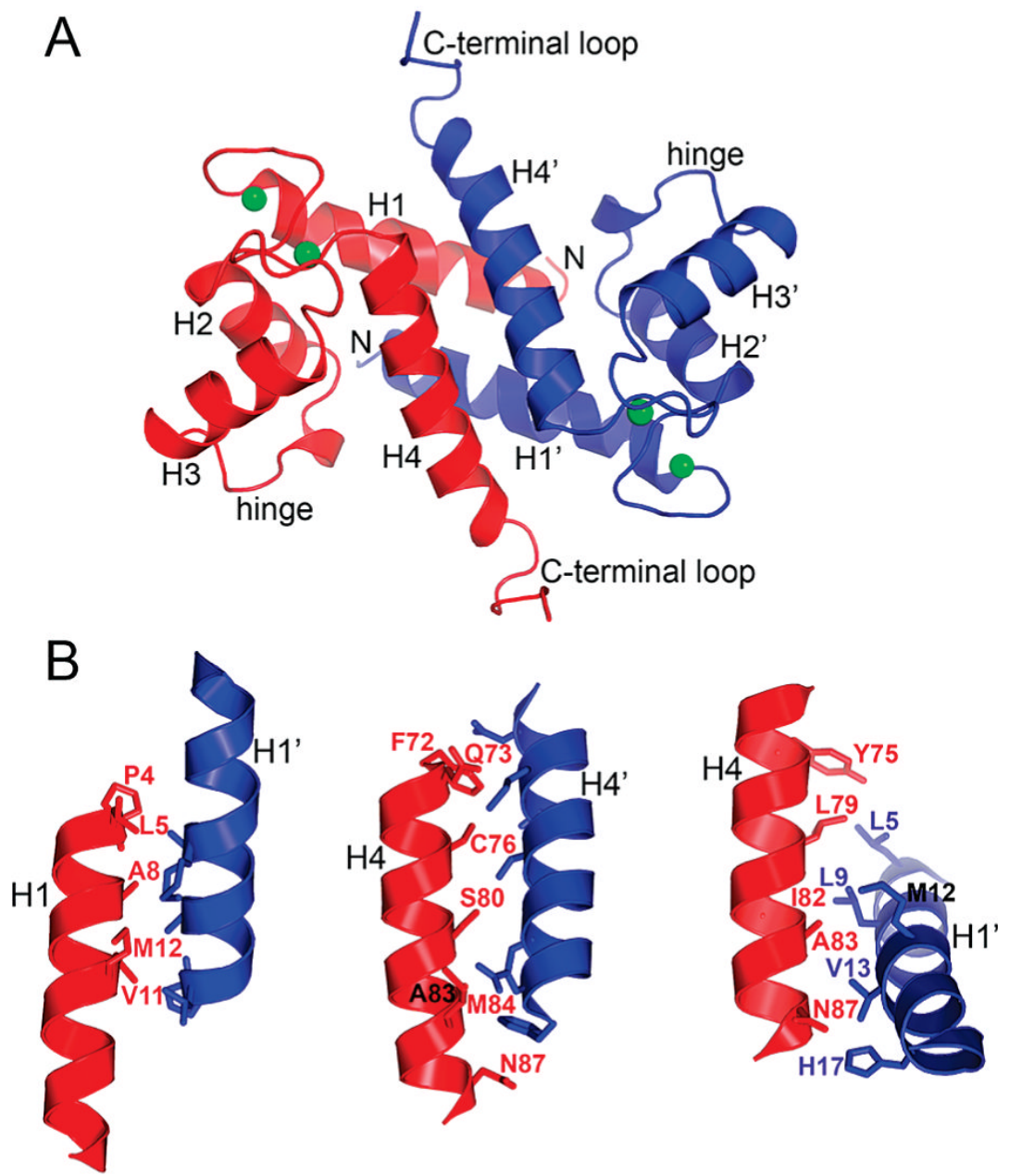

Figure 4.

Molecular architecture of the $\mathrm{Ca}^{2+}{ }_{-} \mathrm{S} 100 \mathrm{~A} 4$ dimer. (A) Ribbon diagram of the dimer, where the two subunits are colored blue and red. The key structural elements common for the S100 family are indicated. Green spheres denote $\mathrm{Ca}^{2+}$ ions. (B) Details of the dimer interface of S100A4 involving helix $1-1^{\prime}, 4-4^{\prime}$, and $1-4^{\prime}\left(1^{\prime}-4\right)$ contact areas. 

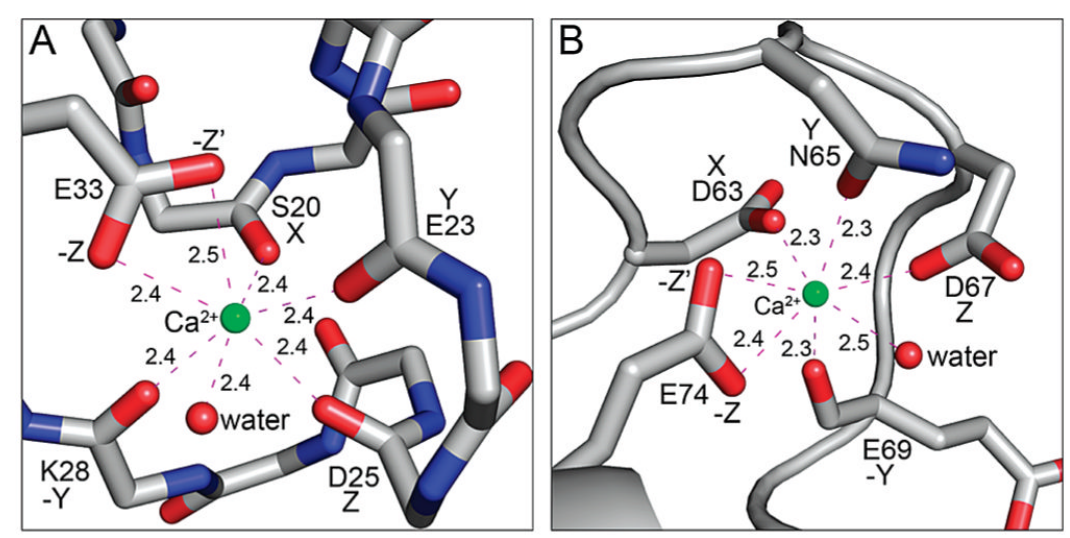

Figure 5.

Structures of the $\mathrm{Ca}^{2+}$-loaded S100A4 EF-hands. (A) N-Terminal pseudo-EF-hand. The $\mathrm{Ca}^{2+}$ ion is coordinated by the main chain carbonyl oxygens of Ser20, Glu23, Asp25, and Lys28; the side chain carboxylate of Glu33 (both oxygens), and a water molecule. (B) CTerminal typical EF-hand. The $\mathrm{Ca}^{2+}$ ion is coordinated by the side chains of Asp63, Asn65, Asp67, and Glu74 (both oxygens); the carbonyl oxygen of Glu69; and a water molecule. Green and red spheres denote $\mathrm{Ca}^{2+}$ and water atoms, respectively. 
A

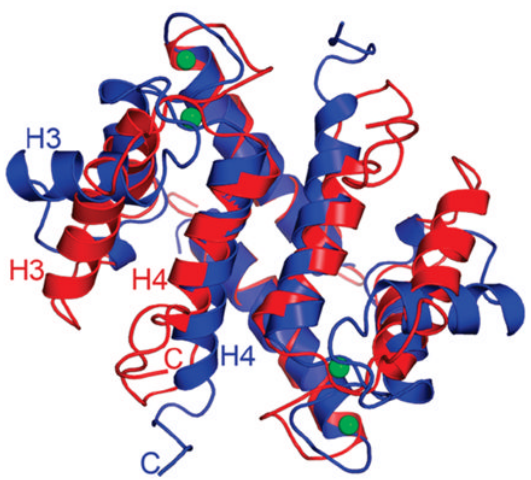

B

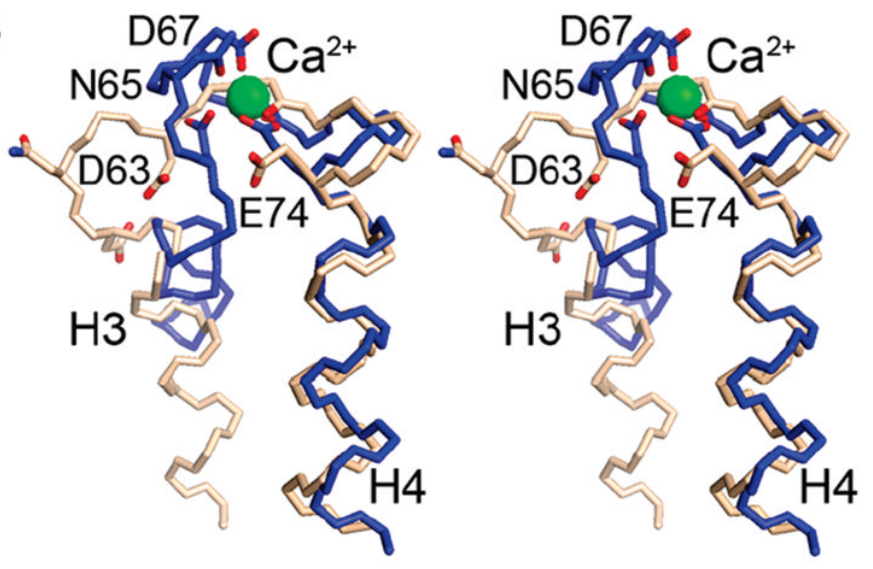

C
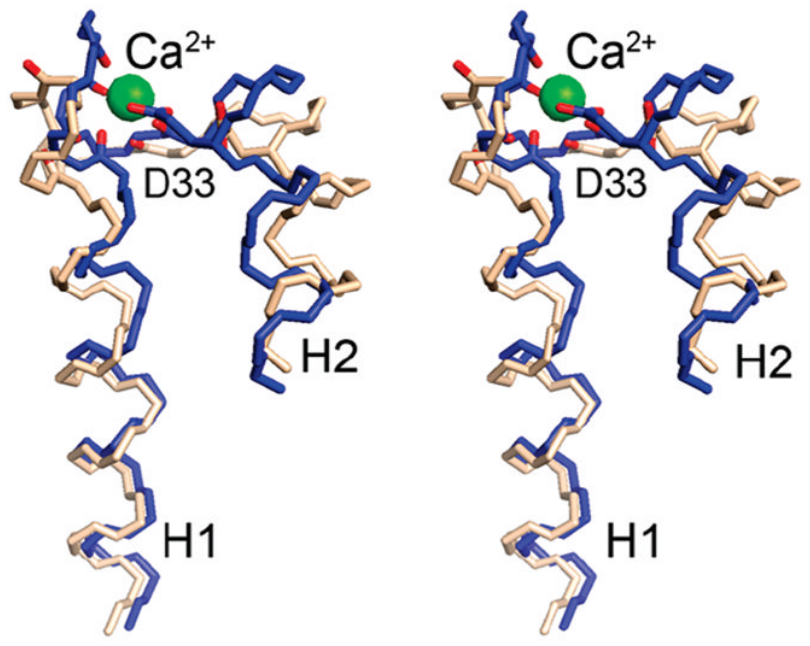

Figure 6.

Conformational rearrangements in S100A4 caused by $\mathrm{Ca}^{2+}$ binding. (A) Ribbon diagrams comparing the three-dimensional structures of apo-S100A4 (red) and $\mathrm{Ca}^{2+}{ }_{-} \mathrm{S} 100 \mathrm{~A} 4$ (blue). Green spheres denote $\mathrm{Ca}^{2+}$ ions. Stereoviews of the (B) pseudo-EF-hand and (C) typical EFhand of apo-S100A4 (beige) and $\mathrm{Ca}^{2+}{ }_{-} \mathrm{S} 100 \mathrm{~A} 4$ (blue). The $\mathrm{Ca}^{2+}$-coordinating oxygen atoms are colored red in both the apo and $\mathrm{Ca}^{2+}$-bound states. 

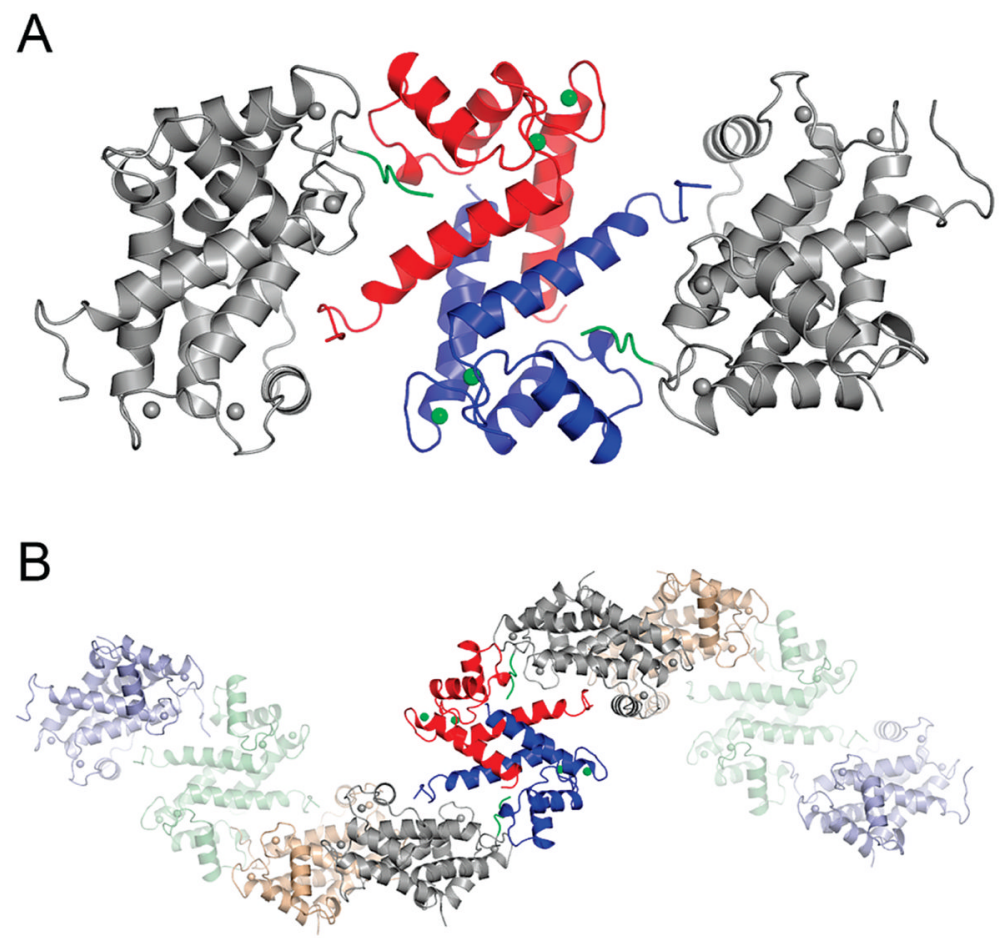

Figure 7.

Self-association of S100A4 molecules in the crystal lattice. (A) The S100A4 dimer is shown with one red and one blue subunit. The symmetry-related molecules (gray) in the S100A4 crystals are positioned such that their C-terminal tails (green) bind to the hydrophobic cleft of the central molecule. (B) The interacting S100A4 dimers form infinite superhelical structures in the crystal. 


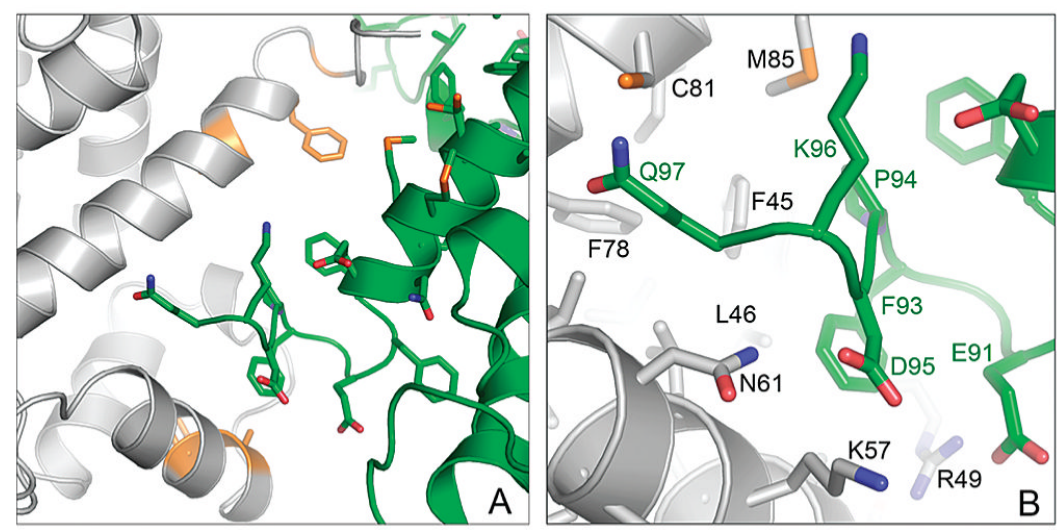

Figure 8.

Interaction of the C-terminal tail of S100A4 (green) with the ligand binding site of the symmetry-related S100A4 molecule (gray). (A) Overall view of the ligand binding pocket. Residues showing chemical shift perturbations upon binding a peptide derived from the Cterminus of S100A4 (residues Glu88-Lys101) are colored orange. (B) Zoomed in view. Many of the interactions are nonpolar; however, Glu91 and Asp95 of the peptide may form ionic interactions with Arg49, Asn61, and Lys57 from the symmetry-related molecule. 

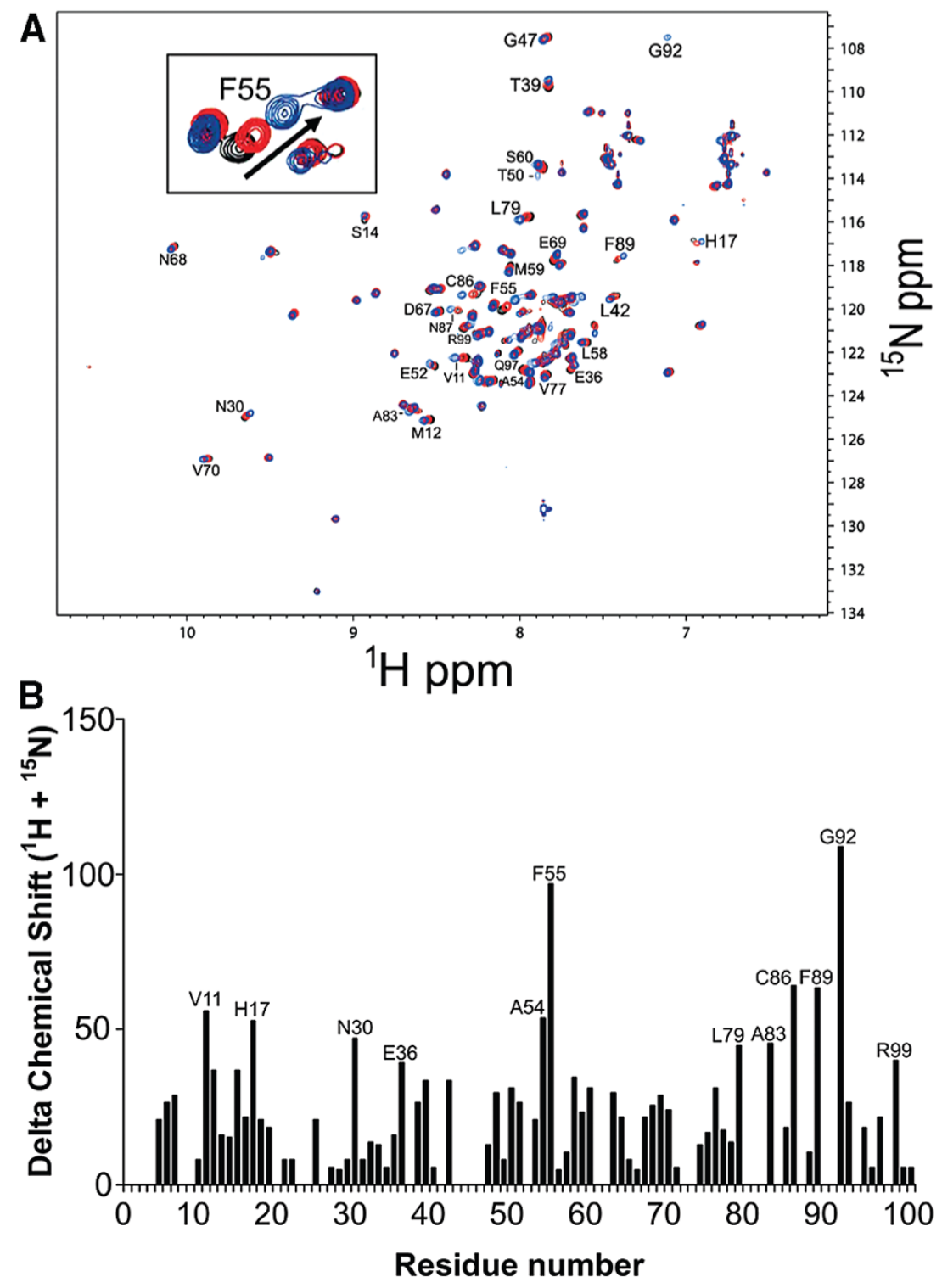

Figure 9.

Chemical shift perturbations of ${ }^{1} \mathrm{H}_{-}{ }^{15} \mathrm{~N}$ correlations in a $2 \mathrm{D}$ HSQC spectrum of $\mathrm{Ca}^{2+}{ }_{-} \mathrm{S} 100 \mathrm{~A} 4$ upon the addition of a peptide derived from the C-terminus of S100A4. (A) HSQC spectra of $\mathrm{Ca}^{2+}-\mathrm{S} 100 \mathrm{~A} 4$ in the absence (black contours) and presence of $0.6 \mathrm{mM}$ (red contours) and 3.6 $\mathrm{mM}$ (blue contours) C-terminal S100A4 peptide. The inset shows an expanded region of the HSQC spectrum illustrating the perturbations to the ${ }^{1} \mathrm{H}-{ }^{15} \mathrm{~N}$ correlation for F55. (B) Chemical shift perturbations for residues in $\mathrm{Ca}^{2+}{ }_{-S} 100 \mathrm{~A} 4$ upon addition of $3.6 \mathrm{mM}$ C-terminal S100A4 peptide. 


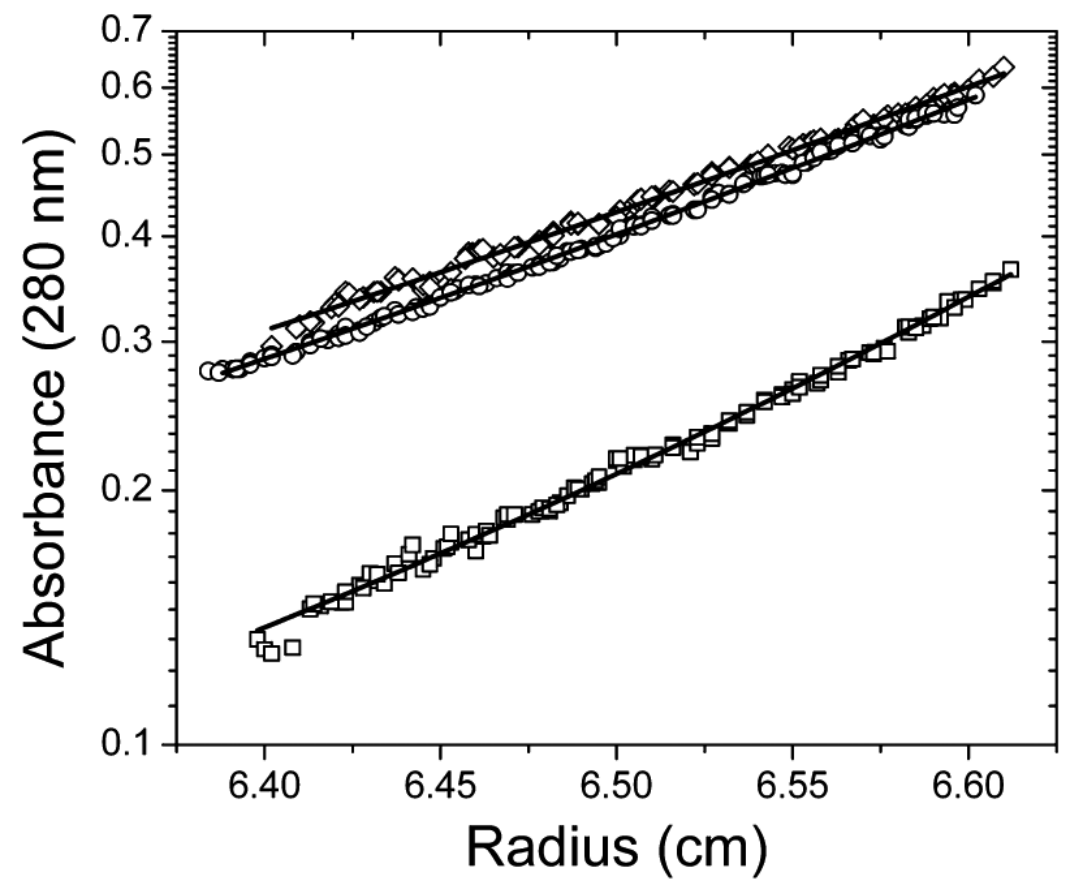

Figure 10.

Sedimentation equilibrium measurements taken at $25^{\circ} \mathrm{C}$. The solid lines represent the best fit from a global nonlinear least-squares analysis of data obtained at 15000 and $22000 \mathrm{rpm}$ : (口) $38 \mu \mathrm{M}$ wild-type $\mathrm{S} 100 \mathrm{~A} 4$ and $\mathrm{CaCl}_{2}$ (subunit concentration), ( ( ) $54 \mu \mathrm{M}$ wild-type S100A4 and EDTA/EGTA (subunit concentration), and $(\diamond) 61 \mu \mathrm{M} \Delta 13 \mathrm{C} \mathrm{S100A} 4$ and $\mathrm{CaCl}_{2}$ (subunit concentration). 


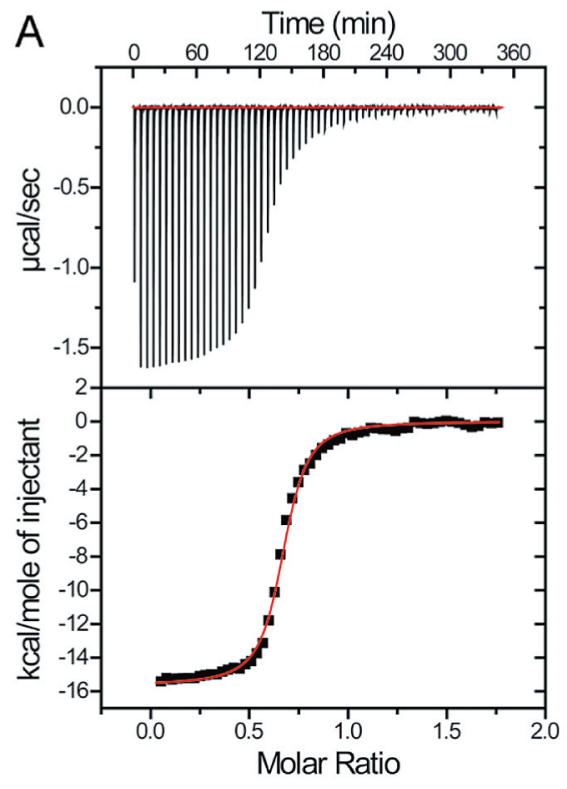

B

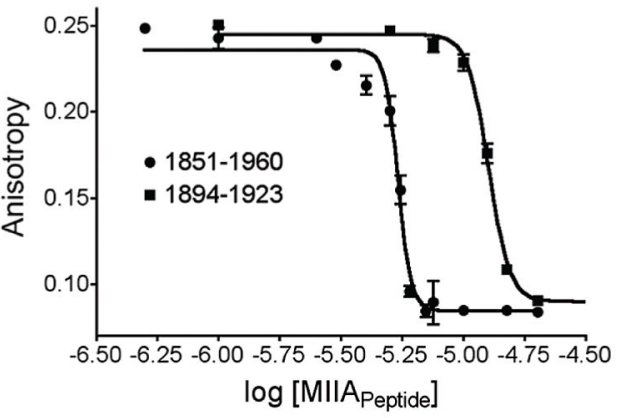

Figure 11.

Thermodynamic data showing MIIA peptide binding to S100A4. (A) Isothermal titration calorimetry (ITC) of MIIA ${ }^{1893-1923}$ peptide (low salt; $n=1$ ). (B) Competition fluorescence anisotropy of MIIA ${ }^{1893-1923}$ and MIIA ${ }^{1851-1960}$ at a physiological salt concentration. 
A

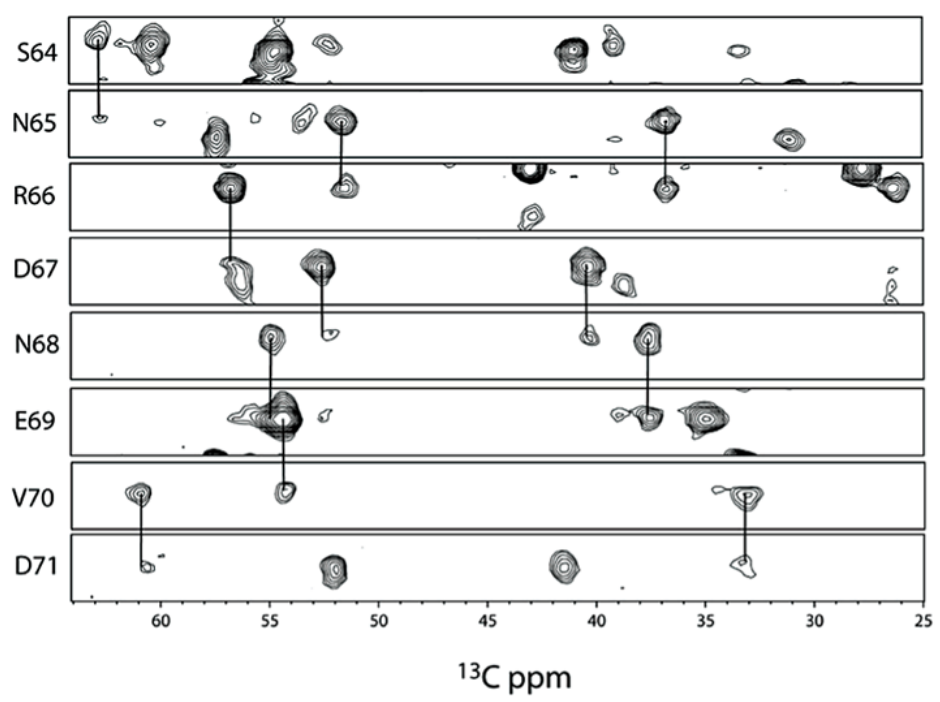

B

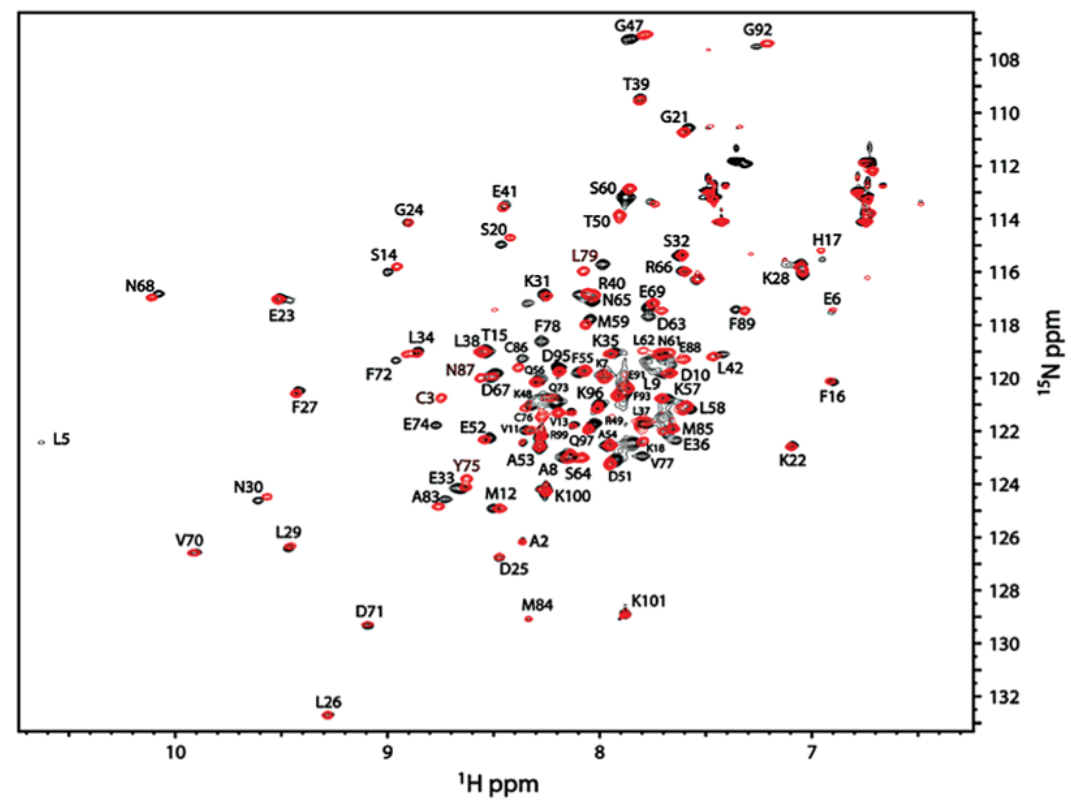

Figure 12.

Nuclear magnetic resonance (NMR) data together with the resonance assignments for $\mathrm{Ca}^{2+}$ S100A4 in the presence and absence of the MIIA ${ }^{1908-1923}$ peptide. (A) Strips from ${ }^{15} \mathrm{~N}$ planes of a three-dimensional HNCACB data set for ${ }^{13} \mathrm{C}$ - and ${ }^{15} \mathrm{~N}$-labeled $\mathrm{S} 100 \mathrm{~A} 4$ bound to the MIIA ${ }^{1908-1923}$ peptide in the presence of $\mathrm{Ca}^{2+}$, which illustrates the quality of the data used for making the resonance assignments. (B) Overlay of ${ }^{1} \mathrm{H}_{-}{ }^{15} \mathrm{~N}$ HSQC data for $\mathrm{Ca}^{2+}{ }_{-} \mathrm{S} 100 \mathrm{~A} 4$ in the MIIA ${ }^{1908-1923}$ peptide-bound (red contours) and free (black contours) states. 
A

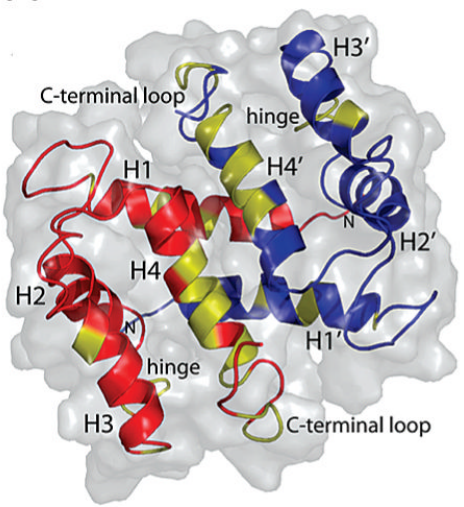

B

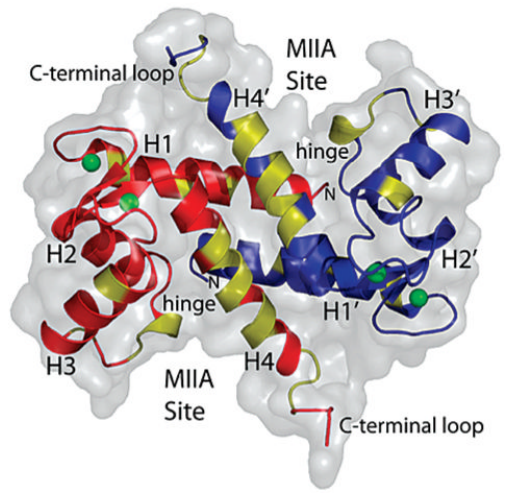

Figure 13.

Ribbon and surface diagrams of S100A4 in the (A) apo and (B) $\mathrm{Ca}^{2+}$-bound states. Residues colored yellow show significant chemical shift perturbations and exchange broadening effects upon binding of the MIIA ${ }^{1908-1923}$ peptide. 
Table 1

Dissociation Constants for $\mathrm{Ca}^{2+}$ Binding to S100A4

\begin{tabular}{lll}
\hline & {$[\mathbf{E F 1}](\boldsymbol{\mu M})$} & {$[\mathbf{E F 2}](\boldsymbol{\mu M})$} \\
\hline S100A4 (low salt) & $54.4 \pm 10.8^{a}$ & $3.3 \pm 1.3^{a}$ \\
S100A4 (high salt) & $>500^{b}$ & $2.6 \pm 1.3^{b}$ \\
S100A4 and MIIA ${ }^{1851-1960}$ (high salt) & $3.6 \pm 0.2^{c}$ & $0.26 \pm 0.01^{c}$ \\
\hline
\end{tabular}

${ }^{a}$ The dissociation constants for $\mathrm{Ca}^{2+}$ binding to each S100A4 EF-hand domain were determined by ITC under low-salt conditions [20 $\mathrm{mM}$ Tris (pH 7.5), $20 \mathrm{mM} \mathrm{KCl}$, and $250 \mu \mathrm{M} \mathrm{TCEP]}$.

${ }^{b}$ These values are from published studies (71). The dissociation constants for $\mathrm{Ca}^{2+}$ binding to each S100A4 EF-hand domain were determined using a 5,5'Br2-BAPTA competition assay under high-salt conditions [20 mM Tris (pH 7.5), $150 \mathrm{mM} \mathrm{KCl,} 1 \mathrm{mM} \mathrm{DTT}$, and 0.02\% NaN3].

${ }^{c}$ The dissociation constants for $\mathrm{Ca}^{2+}$ binding to each S100A4 EF-hand domain in the presence of MIIA $1851-1960$ were determined using a 5,5' $\mathrm{Br} 2-$ BAPTA competition assay under high-salt conditions [20 mM Tris ( $\mathrm{pH} 7.5$ ), $150 \mathrm{mM} \mathrm{KCl,} 1 \mathrm{mM}$ DTT, and 0.02\% NaN3]. 
Table 2

Crystallographic Data and Refinement Statistics

\begin{tabular}{|c|c|c|}
\hline & SAD & native \\
\hline \multicolumn{3}{|c|}{ Data collection } \\
\hline beamline & NSLS-X6A & NSLS-X29A \\
\hline wavelength $(\AA)$ & 1.7 & 1.0 \\
\hline resolution limits $(\AA)$ & $20-1.95$ & $20-1.63$ \\
\hline no. of observed reflections & 299244 & 288354 \\
\hline no. of unique reflections & 16952 & 28584 \\
\hline completeness (\%) & $89.4(50.2)^{a}$ & $99.9(99.9)^{a}$ \\
\hline$R_{\text {merge }} b$ & $0.053(0.367)^{a}$ & $0.096(0.685)^{a}$ \\
\hline \multicolumn{3}{|c|}{ Refinement Statistics } \\
\hline no. of protein non-hydrogen atoms & 2458 & \\
\hline no. of water molecules & 226 & \\
\hline$R_{\text {cryst }}^{c}$ & $0.197(0.245)^{a}$ & \\
\hline$R_{\text {free }}{ }^{c}$ & $0.222(0.302)^{a}$ & \\
\hline average $B$-factor $\left(\AA^{2}\right)$ & 25.1 & \\
\hline \multicolumn{3}{|c|}{ rmsd from Ideality } \\
\hline bond lengths $(\AA)$ & 0.013 & \\
\hline bond angles (deg) & 1.4 & \\
\hline torsion angles (deg) & 23.1 & \\
\hline \multicolumn{3}{|c|}{ Ramachandran plot } \\
\hline core & $92.0 \%$ & \\
\hline allowed & $6.9 \%$ & \\
\hline generous & $1.1 \%$ & \\
\hline
\end{tabular}

${ }^{a}$ Values in parentheses indicate statistics for the high-resolution bin.

${ }^{b} R_{\text {merge }}=\Sigma \Sigma_{j}\left|I_{j}(h k l)-\langle I(h k l)\rangle\right| / \Sigma \Sigma_{j}|\langle I(h k l)\rangle|$, where $I_{j}$ is the intensity measurement for reflection $j$ and $\langle I\rangle$ is the mean intensity over $j$ reflections.

${ }^{c} R_{\text {cryst }} / R_{\text {free }}=\Sigma\left\|F_{O}(h k l)|-| F_{C}(h k l)\right\| \Sigma\left|F_{O}(h k l)\right|$, where $F_{\mathrm{O}}$ and $F_{\mathrm{C}}$ are observed and calculated structure factors, respectively. No $\sigma$ cutoff was applied. Five percent of the reflections were excluded from refinement and used to calculate $R_{\text {free }}$. 
Table 3

Structural Differences between Apo and $\mathrm{Ca}^{2+}{ }_{-} \mathrm{S} 100 \mathrm{~A} 4$ and Other S100 Proteins

\begin{tabular}{|c|c|c|c|}
\hline & \multicolumn{2}{|c|}{ rms deviation between $C_{a}$ atoms $(\AA) / Z$ score ${ }^{a}$} & \multirow[b]{2}{*}{$\begin{array}{l}\text { sequence } \\
\text { identity }(\%)\end{array}$} \\
\hline & apo $^{b}$ & $\mathrm{Ca}^{2+}$-bound $c$ & \\
\hline S100A1 & $3.2 / 7.3^{d}(86)$ & $2.6 / 10.3^{e}(92)$ & 49 \\
\hline S100A6 & $2.1 / 9.6^{f}(84)$ & $1.5 / 15.1^{g}(89)$ & 50 \\
\hline S100A7 & $\mathrm{n} / \mathrm{a}$ & $2.3 / 11.3^{h}(87)$ & 27 \\
\hline S100A8 & $\mathrm{n} / \mathrm{a}$ & $2.2 / 13.3^{i}(88)$ & 34 \\
\hline S100A9 & $\mathrm{n} / \mathrm{a}$ & $1.3 / 13.0^{j}(81)$ & 32 \\
\hline S100A11 & $3.2 / 7.0^{k}(87)$ & $2.0 / 14.5^{l}(95)$ & 27 \\
\hline S100A12 & $\mathrm{n} / \mathrm{a}$ & $1.5 / 14.3^{m}(87)$ & 40 \\
\hline S100A13 & $3.7 / 7.0^{n}(83)$ & $1.5 / 14.5^{\circ}(86)$ & 34 \\
\hline S100B & $3.5 / 8.4^{p}(88)$ & $2.4 / 11.7^{q}(92)$ & 48 \\
\hline $\begin{array}{l}\text { calbindin } \\
\text { D9K }\end{array}$ & $3.1 / 4.6^{r}(67)$ & $1.9 / 11.7^{s}(73)$ & 38 \\
\hline calcyclin & $2.9 / 9.1^{t}(87)$ & $2.8 / 10.5^{u}(88)$ & 51 \\
\hline
\end{tabular}

${ }^{a}$ Calculated using DaliLite (47); values in parentheses indicate the number of superimposed atoms.

${ }^{b}$ PDB entry 1M31 (23).

${ }^{c}$ PDB entry 2Q91 (this work).

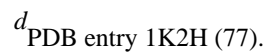

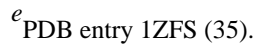

$f_{\text {PDB entry } 1 \mathrm{~K} 9 \mathrm{P}(76) \text {. }}$

$g_{\text {PDB entry } 1 \text { K96 (76). }}$

$h_{\text {PDB entry 1PSR (100). }}$

${ }^{i}$ PDB entry 1MR8 (105).

${ }^{j}$ PDB entry 1IRJ (106).

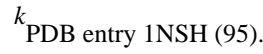

$l_{\text {PDB entry 1QLS (96). }}$

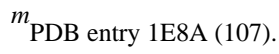

${ }^{n}$ PDB entry 1YUR (97).

${ }^{o}$ PDB entry $2 \mathrm{H} 2 \mathrm{~K}(98)$.

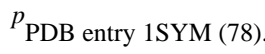

${ }^{q} \mathrm{PDB}$ entry $1 \mathrm{QLK}$ (34).

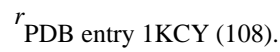


${ }^{s}$ PDB entry 4ICB (108).

${ }^{t}$ PDB entry 2CNP (75).

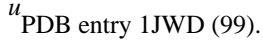




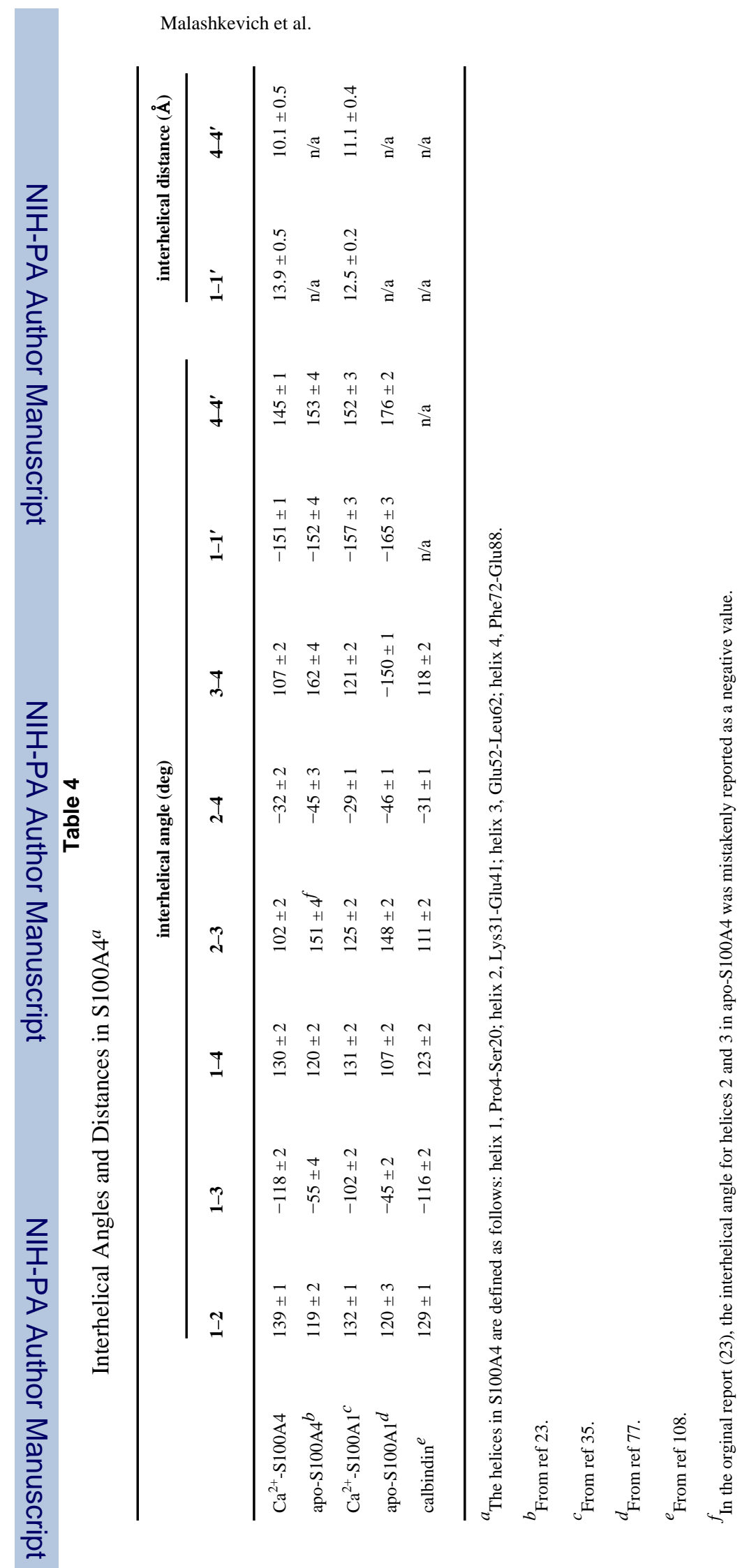

Biochemistry. Author manuscript; available in PMC 2009 January 30. 


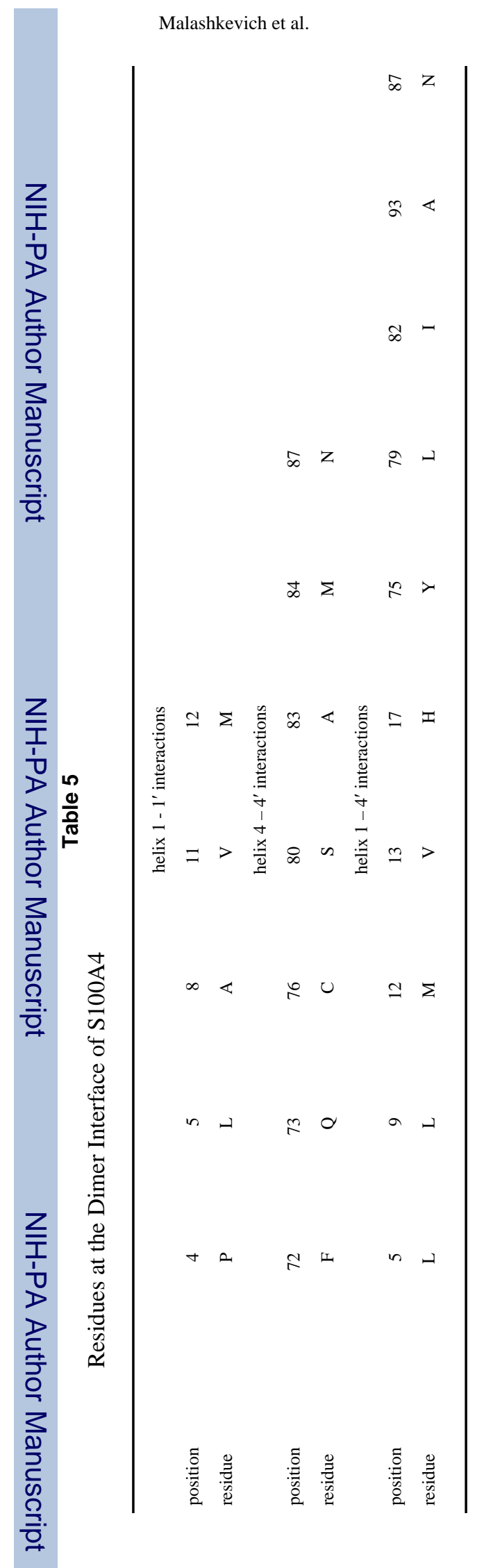

Page 37 


\section{Table 6}

Dissociation Constants for MIIA Binding to S100A4

\begin{tabular}{|c|c|}
\hline MIIA construct & $K_{\mathrm{d}}(\mu \mathrm{M})$ \\
\hline S100A4 + MIIA ${ }^{1338-1960}$ (rod, low salt) & $2.7 \pm 0.6^{a}$ \\
\hline S100A4 + MIIA ${ }^{1851-1960}$ (coiled coil + tailpiece, low salt) & $0.41 \pm 0.01^{b}$ \\
\hline S100A4 + MIIA ${ }^{1851-1960}$ (coiled coil + tailpiece, high salt) & $0.50 \pm 0.01^{b}$ \\
\hline S100A4 + MIIA ${ }^{1893-1923}$ (coiled coil, low salt) & $0.34 \pm 0.02^{c}$ \\
\hline S100A4 + MIIA ${ }^{1893-1923}$ (coiled coil, high salt) & $1.1 \pm 0.1^{d}$ \\
\hline S100A4 + MIIA ${ }^{1908-1923}$ (minimal S100A4 site, low salt) & $0.50 \pm 0.20^{e}$ \\
\hline S100A4 + MIIA ${ }^{1908-1923}$ (minimal S100A4 site, low salt) & $0.89 \pm 0.12^{f}$ \\
\hline S100A4 + MIIA ${ }^{1908-1923}$ (minimal S100A4 site, high salt) & $1.7 \pm 0.2^{f}$ \\
\hline
\end{tabular}

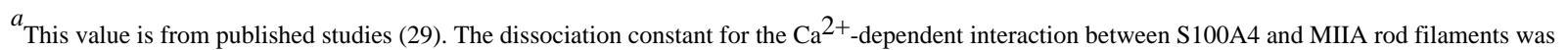
determined in a cosedimentation assay under low-salt conditions [20 mM Tris ( $\mathrm{pH} 7.5$ ), $20 \mathrm{mM} \mathrm{NaCl}, 2 \mathrm{mM} \mathrm{MgCl}, 0.3 \mathrm{mM} \mathrm{CaCl} 2,1 \mathrm{mM} \mathrm{DTT}, 0.02 \%$ $\mathrm{NaN} 3$ ]. Binding could not be examined under high-salt conditions $(150 \mathrm{mM} \mathrm{KCl})$ since S100A4 disassembles the MIIA rods under these conditions.

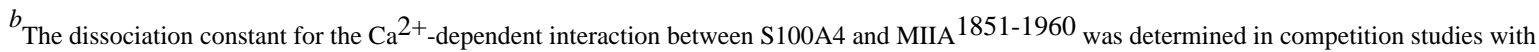
fluorescently labeled MIIA ${ }^{1908-1923}$ using a fluorescence polarization assay under low- and high-salt conditions [20 mM Tris (pH 7.5), 20 or 150 mM $\mathrm{KCl}, 1 \mathrm{mM}$ DTT, $0.02 \% \mathrm{NaN}_{3}$, and $0.5 \mathrm{mM} \mathrm{CaCl}_{2}$ ]. MIIA $1851-1960$ comprises part of the coiled-coil domain and the C-terminal tailpiece of MIIA.

$c^{c}$ The dissociation constant for the $\mathrm{Ca}^{2+}$-dependent interaction between S100A4 and MIIA $1893-1923$ was determined using ITC under low-salt conditions [20 mM Tris (pH 7.5), $20 \mathrm{mM} \mathrm{KCl}, 250 \mu \mathrm{M}$ TCEP, and $0.8 \mathrm{mM} \mathrm{CaCl}_{2}$ ]. MIIA $1893-1923$ comprises part of the coiled-coil domain of MIIA.

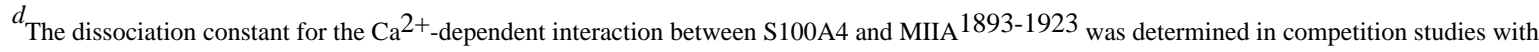
fluorescently labeled MIIA ${ }^{1908-1923}$ using a fluorescence polarization assay under high-salt conditions [20 mM Tris (pH 7.5), $150 \mathrm{mM} \mathrm{KCl,} 1 \mathrm{mM}$ DTT, $0.02 \% \mathrm{NaN}_{3}$, and $0.5 \mathrm{mM} \mathrm{CaCl}_{2}$.

${ }^{e}$ The dissociation constant for the $\mathrm{Ca}^{2+}$-dependent interaction between S100A4 and MIIA ${ }^{1908-1923}$ was determined using ITC under low-salt conditions [20 mM Tris (pH 7.5), $20 \mathrm{mM} \mathrm{KCl}, 250 \mu \mathrm{M}$ TCEP, and $0.8 \mathrm{mM} \mathrm{CaCl}_{2}$ ]. MIIA $1908-1923$ comprises a portion of the coiled-coil domain of MIIA but is not predicted to form a coiled coil.

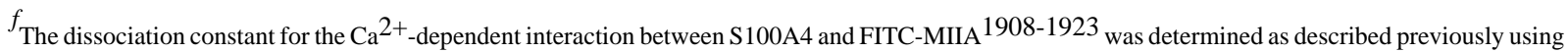
a fluorescence polarization assay (71) under low- or high-salt conditions [20 mM Tris (pH 7.5), 20 or $15 \mathrm{mM} \mathrm{KCl,} 1 \mathrm{mM} \mathrm{DTT}, 0.02 \%$ NaN3, and 0.5 $\left.\mathrm{mM} \mathrm{CaCl}_{2}\right]$. 